The University of Maine

\title{
DigitalCommons@UMaine
}

Earth Science Faculty Scholarship

Earth Sciences

$1-3-2008$

\section{Metamorphism, Transient Mid-Crustal Rheology, Strain Localization and the Exhumation of High- Grade Metamorphic Rocks}

Wesley G. Groome

Peter O. Koons

University of Maine - Main, peter.koons@maine.edu

Scott E. Johnson

University of Maine - Main, johnsons@maine.edu

Follow this and additional works at: https://digitalcommons.library.umaine.edu/ers_facpub

Part of the Earth Sciences Commons

\section{Repository Citation}

Groome, Wesley G.; Koons, Peter O.; and Johnson, Scott E., "Metamorphism, Transient Mid-Crustal Rheology, Strain Localization and the Exhumation of High-Grade Metamorphic Rocks" (2008). Earth Science Faculty Scholarship. 61.

https://digitalcommons.library.umaine.edu/ers_facpub/61 


\title{
Metamorphism, transient mid-crustal rheology, strain localization and the exhumation of high-grade metamorphic rocks
}

\author{
Wesley G. Groome, ${ }^{1,2}$ Peter O. Koons, ${ }^{1}$ and Scott E. Johnson ${ }^{1}$ \\ Received 10 May 2006; revised 2 August 2007; accepted 6 September 2007; published 3 January 2008.
}

[1] We present a series of three-dimensional numerical models investigating the effects of metamorphic strengthening and weakening on the geodynamic evolution of convergent orogens that are constrained by observations from an exposed mid-crustal section in the New England Appalachians. The natural midcrustal section records evidence for spatially and temporally variable mid-crustal strength as a function of metamorphic grade during prograde polymetamorphism. Our models address changes in strain rate partitioning and topographic uplift as a function of strengthening/ weakening in the middle crust, as well as the resultant changes in deformation kinematics and potential exhumation patterns of high-grade metamorphic rock. Results suggest that strengthening leads to strain rate partitioning around the zone and suppressed topographic uplift rates whereas weakening leads to strain rate partitioning into the zone and enhanced topographic uplift rates. Deformation kinematics recorded in the orogen are also affected by strengthening/weakening, with complete reversals in shear sense occurring as a function of strengthening/ weakening without changes in plate boundary kinematics. Citation: Groome, W. G., P. O. Koons, and S. E. Johnson (2008), Metamorphism, transient mid-crustal rheology, strain localization and the exhumation of high-grade metamorphic rocks, Tectonics, 27, TC1001, doi:10.1029/2006TC001992.

\section{Introduction}

[2] Changes in lithosphere rheology during orogenesis can fundamentally alter the geodynamic evolution of orogenic belts. Changes in rheology can arise through diverse processes including thermal weakening from asthenospheric heating or magmatism [e.g., Arzi, 1978; Hollister and Crawford, 1986; Gualteri et al., 1998; Handy et al., 2001], focused erosion leading to the rapid exhumation of hot, weak rock to shallower depths [e.g., Zeitler et al., 1993; Jamieson et al., 2002; Koons et al., 2002; Beaumont et al., 2004; Pysklywec, 2006] or metamorphism [e.g., Rubie,

\footnotetext{
${ }^{1}$ Department of Earth Sciences, University of Maine, Orono, Maine, USA.

${ }^{2}$ Now at Department of Earth Sciences, Simon Fraser University, Burnaby, British Columbia, Canada.

Copyright 2008 by the American Geophysical Union. 0278-7407/08/2006TC001992
}

1983; Brodie and Rutter, 1987; Koons et al., 2003a; Barnes et al., 2004; Jolivet et al., 2005; Holyoke and Tullis, 2006]. As the rheology of the lithosphere changes during orogenesis, the distribution of deformation, topographic uplift and potentially the thermal state of the orogen can be affected. In eastern New Hampshire, an exposed mid-crustal section preserves evidence for sequential rheologic strengthening and weakening during prograde metamorphism associated with Devonian Acadian Orogenesis [Groome and Johnson, 2006; Groome et al., 2006]. Early metamorphic strengthening was associated with a phase of andalusite-grade metamorphism at approximately $406 \mathrm{Ma}$ [Eusden et al., 1996; Eusden et al., 2000] and subsequent metamorphic weakening was associated with a phase of sillimanite-grade metamorphism that included the development of a widespread migmatite terrane at approximately $404 \mathrm{Ma}$ [e.g., Allen, 1992; Eusden et al., 1996; Eusden et al., 2000]. The strengthening effects of andalusite-grade metamorphism were assessed using foliation refraction angles [Groome and Johnson, 2006] and bed-scale numerical models [Groome et al., 2006] and the effects of metamorphic weakening associated with partial melting were qualitatively assessed using field data, including the observation of strain partitioning into units that have experienced partial melting [Groome, 2006].

[3] In this paper, we use three-dimensional numerical models, broadly constrained by observations from the New Hampshire example discussed above, to assess the orogenscale geodynamic effects of mid-crustal metamorphic strengthening and weakening. The results presented here build upon preliminary orogen-scale models presented by Groome et al. [2006] that assessed the potential effects of mid-crustal metamorphic strengthening on the topographic evolution of an orogen. However, the models presented here differ from those presented by Groome et al. [2006] because we include a component of metamorphic weakening, assess the effects of location within the orogen where strengthening and weakening occurs and investigate the deformation partitioning signature of strengthening and weakening.

[4] Analog [e.g., Barraud et al., 2001], numerical [e.g., Beaumont et al., 2001; Koons et al., 2002; Jamieson et al., 2002; Medvedev, 2002; Beaumont et al., 2004] and conceptual [e.g., Rubie, 1983; Hollister and Crawford, 1986; Brodie and Rutter, 1987; Koons et al., 1987; Freuh-Green, 1994; Brown and Solar, 1998; Daniel et al., 2003; Barnes et al., 2004] models addressing the role of metamorphic weakening, particularly during partial melting, suggest that significant weakening will lead to strain localization within the weak zone and enhanced exhumation rates in and around the weakened zone. Furthermore, large orogenic 
plateaus such as the Altiplano [e.g., Babeyko et al., 2002; Husson and Sempere, 2003] have been attributed to the presence of a melt layer in the deep crust reducing the basal friction of the orogenic wedge, which largely controls the topographic slope [e.g., Dahlen and Suppe, 1984].

[5] The geodynamic consequences of strong lithospheric blocks have been investigated for the Himalaya [e.g., Molnar and Tapponnier, 1981; Vilotte et al., 1984; England and Houseman, 1985; Neil and Houseman, 1997], and these models suggest that strain will partition around strong blocks and result in the formation of basins surrounded by uplifting regions of higher strain. The Tarim Basin in western China is located between the actively uplifting Tibetan Plateau and the Tien Shan and is thought to be underlain by a lithosphere-scale (in excess of $500 \mathrm{~km}$ across) block of strong crust [e.g., Molnar and Tapponnier, 1981; Neil and Houseman, 1997]. In this paper we investigate the effects of smaller blocks (on the order of $40 \mathrm{~km}$ across) of strong and weak middle crust, resulting from prograde metamorphic strengthening and weakening, on the geodynamic evolution of collisional orogens. We are particularly interested in the effects of strong and weak zones on the topographic uplift and strain rate distribution within an orogen. We test the sensitivity of model results to: 1) position of the block in the orogen, 2) the sense of strength contrast (i.e., whether the block is stronger or weaker than the surrounding crust) and 3) the magnitude of the strength contrast.

\section{Conceptual Model}

[6] The topography of an orogen is a coupled response to material properties of the lithosphere, the kinematics of plate convergence and erosion [e.g., Dahlen and Suppe, 1984; Koons, 1990; Willet et al., 2003; Williams et al., 1994; Beaumont et al., 1996]. The long wavelength topography of collisional orogens has generally been described in terms of critical wedge dynamics, which relates the surface slope of an orogenic wedge to the internal strength of the lithosphere, the dip of the basal decollement and the frictional strength of the basal decollement [e.g., Dahlen and Suppe, 1984; Davis et al., 1983; Koons, 1987, 1990; Williams et al., 1994; Enlow and Koons, 1998]. Critical wedge dynamics suggests that topographic slope is largely a function of: 1) the dip and strength of the basal decollement and 2) the internal strength of material in the wedge [e.g., Dahlen and Suppe, 1984; Enlow and Koons, 1998]. Critical wedge dynamics generally provide a good description of the relationship between surface slope and material properties for thin-skinned fold-and-thrust belts and accretionary prisms; however, processes occurring below the brittleductile transition are not generally considered for explaining thin-skinned fold-and-thrust belts [e.g., Dahlen and Suppe, 1984; Woodward, 1987]. Notable exceptions to this generalization include the recognition that the involvement of material below the brittle-ductile transition in many thickskinned orogenic belts corresponds to a change in surface slope [e.g., Koons, 1990; Williams et al., 1994; Carminati and Siletto, 1997]; however, the rheology of the crust below the brittle-ductile transition is generally viewed as a homogeneously weakening material.

[7] In many deeply eroded orogenic belts, there is abundant field evidence for spatial and temporal variability in mid- and lower-crustal strength. For example, large migmatite terranes are common and are generally regarded as weakened zones [e.g., Hollister and Crawford, 1986; Brown and Solar, 1998]. Conceptual and numerical models investigating the geodynamic effects of weakening, either via partial melting or hydration metamorphism, generally agree that weakening in the middle and lower crust results in strain localization into the weakened zone, which can variably alter the uplift rates of high-grade rocks depending on where in the orogen partial melting occurs [e.g., Hollister and Crawford, 1986; Brown and Solar, 1998; Beaumont et al., 2001, 2004; Jamieson et al., 2002]. More enigmatic, however, are zones of increased strength in the middle and lower crust resulting either from the effects of prograde metamorphism or more transient processes such as reductions in pore pressure [e.g., Axen et al., 2001; Bauer et al., 2000; Handy et al., 2001; Selverstone, 2005]. The presence of large zones of strengthening in the middle and lower crust should affect the geodynamic evolution of an orogen as significantly as large weakened zones.

[8] To test the effects of strengthened and weakened zones on the geodynamic evolution of a collisional orogen, a conceptual model was developed for regional-scale metamorphism in the middle crust involving subduction of a moderately thick oceanic plate (or alternatively a moderately thin continental plate) with accretion at the toe of a developing orogen (Figure 1). Regional-scale mid-crustal metamorphism in the overriding plate is driven in part by an elevated geotherm above a zone of asthenospheric counterflow, which also has the effect of thermally weakening the overriding plate. Our model results are only mechanical solutions, without accompanying thermal solutions, and we place strong and weak zones in the middle crust at appropriate depths for low-pressure, high-temperature metamorphism as seen in our field example. The depths to the zones of strengthening and weakening are constrained by assuming that the models result in regional low-pressure, hightemperature metamorphism in the andalusite stability field for metamorphic strengthening and in the sillimanite stability field for metamorphic weakening, which corresponds to constraints imposed by our natural example (see below). We recognize, however, that the mechanical solutions generated will have thermal consequences, and we address these consequences in a qualitative manner in this paper.

\section{Observational Basis for the Model}

[9] The White Mountains area of eastern New Hampshire (Figure 2) is an excellent natural laboratory to examine the evolution of mechanical stratigraphy in the middle crust during syn-orogenic low-pressure, high-temperature metamorphism. This area preserves evidence for two periods of regionally extensive, prograde low-pressure, high temperature metamorphism and two regionally extensive phases of deformation associated with the Acadian Orogeny [e.g., 


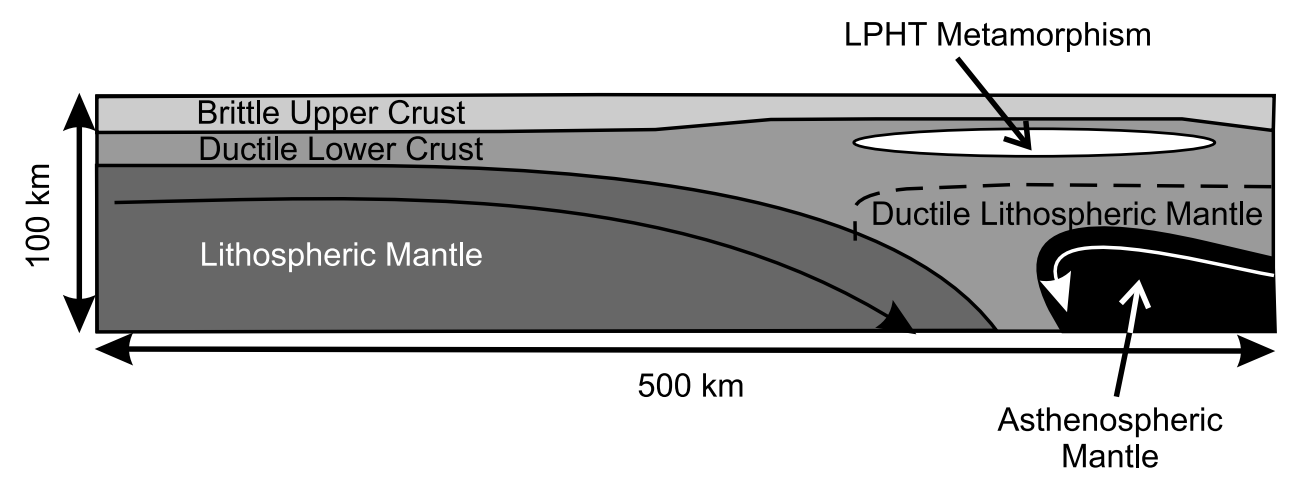

Figure 1. Conceptual model for the development of regional-scale low-pressure, high-temperature metamorphic belts resulting from asthenospheric mantle upwelling. The upwelling, hot asthenospheric mantle contributes heat to the overriding lithosphere, resulting in low-pressure, high-temperature metamorphism and overall lithospheric weakening.

Billings et al., 1946; Hatch et al., 1983; Wall, 1988; Allen, 1992, 1996; Eusden et al., 1996, 2000].

[10] Early metamorphic strengthening occurred at approximately $406 \mathrm{Ma}$ during a period of syn-kinematic andalusite-grade metamorphism that resulted in the formation of large (10-15 cm long) andalusite porphyroblasts, which form an almost load-bearing framework, in pelitic units, along with smaller staurolite and garnet porphyroblasts [e.g., Wall, 1988; Eusden et al., 1996, 2000]. Andalusite growth was probably early syn-kinematic with a phase of km-scale nappe folding, as suggested by anastamosing nappe-stage foliations around the porphyroblasts, and the local alignment of andalusite porphyroblasts to form a mineral lineation that lies in the plane of the nappe fold axial planes [e.g., Eusden et al., 1996; Groome and Johnson, 2006]. The extent of andalusite-grade metamorphism in the study area is obscured by a subsequent metamorphic overprint at approximately $404 \mathrm{Ma}$ that included the formation of an extensive migmatite terrane [e.g., Wall, 1988; Allen, 1992; Eusden et al., 2000]; however the minimum original extent of andalusite can be deduced from the extent of pseudomorphs after andalusite. In the White Mountains region, pseudomorphs after andalusite are present in an approximately $50 \mathrm{~km}^{2}$ area, and on a regional scale early andalusite-grade metamorphism is recognized sporadically in an approximately $4000 \mathrm{~km}^{2}$ area [e.g., Guidotti, 1989].

[11] The rocks constituting the field area were deposited in a foreland basin along the inboard margin of the Acadian Orogen [e.g., Van Staal et al., 1998] and were subsequently incorporated into the growing orogen. By $406 \mathrm{Ma}$, the age of andalusite-grade metamorphism, the Acadian orogenic front was located several $\mathrm{km}$ to the northeast of the study area [e.g., Bradley et al., 2000], and the currently exposed mid-crustal section was located in the inboard region of the orogenic core (Figure 2). Subsequent to $406 \mathrm{Ma}$, the Acadian orogenic front continued to migrate to the northeast [e.g., Bradley et al., 2000], and by the time of partial melting in the field area (404 Ma), the study area would have been located in the core of the orogen.
[12] The strengthening effect of andalusite growth in the White Mountains region was assessed using field data to constrain the effective viscosity ratio between porphyroblast-rich pelitic schists and porphyroblast-free quartzofeldspathic psammites [Groome and Johnson, 2006] and by bed-scale finite element modeling [Groome et al., 2006] (Figure 3). Using foliation refraction angles to estimate the relative effective viscosities of porphyroblast-rich pelitic schists and porphyroblast-free psammites, Groome and Johnson [2006] determined that the porphyroblastic schists were approximately twice as viscous as the porphyroblastfree psammites. The use of foliation refraction angles is based on the geometric relationship between bedding-foliation angles $(\theta)$ in two adjacent units (A and B) and the amount of finite shear strain $(\gamma)$ recorded in each unit, which is taken as a proxy for the effective viscosity $(\eta)$ of a given unit [e.g., Treagus, 1999]:

$$
\frac{\gamma_{A}}{\gamma_{B}}=\frac{\tan \theta_{B}}{\tan \theta_{A}}=\frac{\eta_{B}}{\eta_{A}}
$$

At lower grades, porphyroblast-free pelitic schists are generally considered to be weaker than quartzo-feldspathic psammites by between 2 and 10 times [e.g., Treagus, 1999; Kenis et al., 2005]. Thus Groome and Johnson [2006] concluded that the higher effective viscosity of porphyroblastic pelitic schists was due to the presence of large, essentially rigid, andalusite porphyroblasts.

[13] Later metamorphic weakening in the White Mountains region occurred during a phase of sillimanite-grade metamorphism accompanied by widespread partial melting, both of which overprinted the early andalusite-grade metamorphic assemblages [e.g., Wall, 1988; Allen, 1992; Eusden et al., 1996]. This phase of metamorphism resulted in the formation of a well-defined metamorphic field gradient from staurolite-zone assemblages in the lowest grade zone to migmatite in the highest grade zone [e.g., Wall, 1988]. In unmigmatized schists, early andalusite porphyroblasts are variably pseudomorphed by coarse-grained muscovite, fine grained staurolite and fibrolitic and blocky sillimanite. 


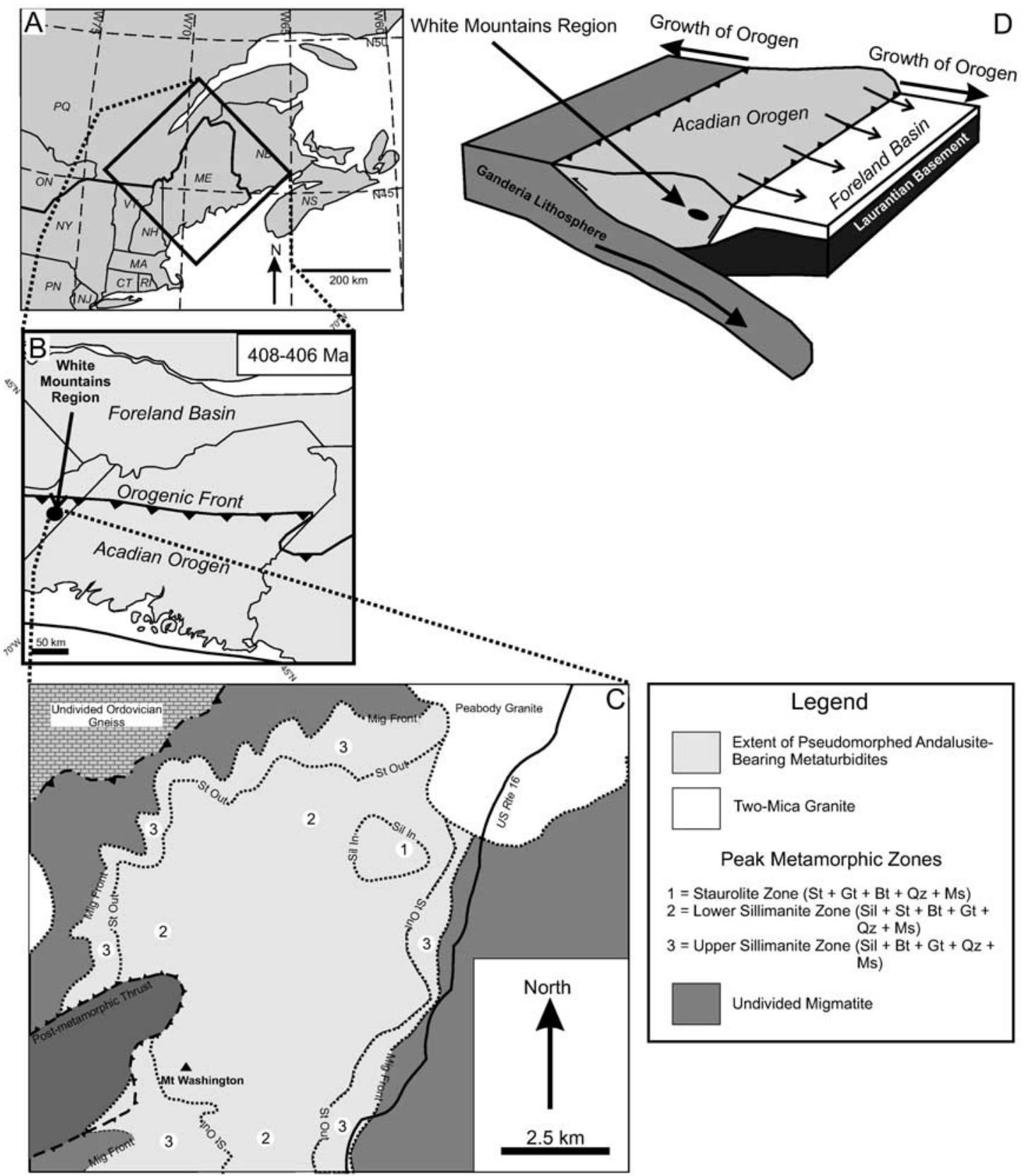

Figure 2. (a) Location map showing the White Mountains region of eastern New Hampshire. (b) Location of the Acadian Orogenic Front at the time of andalusite-grade metamorphism in the White Mountains (modified from Bradley et al. [2000]). The Study Area was located near the migrating orogenic front at this time. (c) Simplified metamorphic assemblage map for the study area showing the geographic extent of andalusite-grade metamorphism and overprinting sillimanite-grade metamorphism. The extent of andalusite-grade metamorphism provides a minimum limit on the region affected by metamorphic strengthening and the extent of the migmatite unit provides constraints on the minimum size of the region that experienced metamorphic weakening. (d) Cartoon showing the position of the White Mountains region within the Acadian Orogen at the time of andalusite-grade metamorphism.

Pseudomorphs after andalusite are commonly folded, suggesting that the pseudomorph assemblage led to weakening in the metapelitic units because the andalusite porphyro- blasts were no longer effectively rigid objects in the metapelitic units.

[14] Widespread migmatization was synchronous with sillimanite-grade metamorphism, which led to additional 

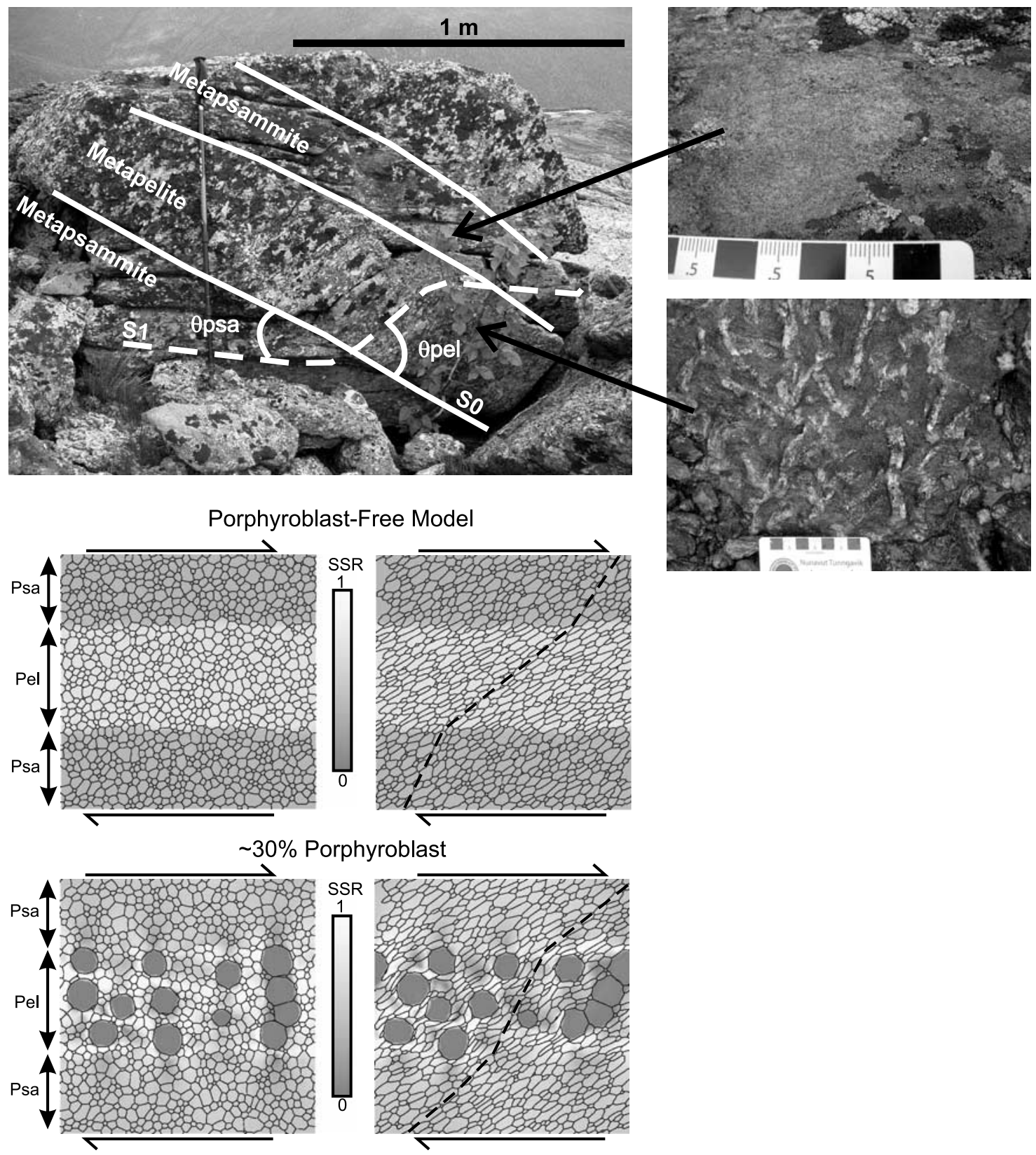

Figure 3. Photograph of refracting $\mathrm{S} 1$ foliation at the contact between porphyroblast-rich metapelitic layers (pel) and porphyroblast-free metapsammitic layers (psa). The larger bedding-foliation angles in the metapelitic unit suggest that these units were stronger than the metapsammitic units. Close-up photographs show typical metapsammite and porphyroblast-rich metapelite units from the study area. Large porphyroblasts are pseudomorphs of muscovite+sillimanite after andalusite. Also shown are twodimensional numerical experiment results showing the changing foliation refraction patterns between porphyroblast-free and porphyroblast-rich pelitic and porphyroblast-free psammitic units. Contours are of shear strain rate (SSR) and the microstructural geometry is overlaid. Deformation is by layer-parallel simple shear in both models. See Groome et al. [2006] for further details.

weakening in this mid-crustal section. Comparatively high degrees of strain are recorded in the migmatite zone, including nearly ubiquitous northeast-southwest oriented dextral shear zones, tight to isoclinal folds, and boudined psammite layers, suggesting that the migmatite zone was weak relative to the unmigmatized schist (Figure 4). In unmigmatized rocks, the only structures with similar kinematics to the shear zones in the migmatites are small 

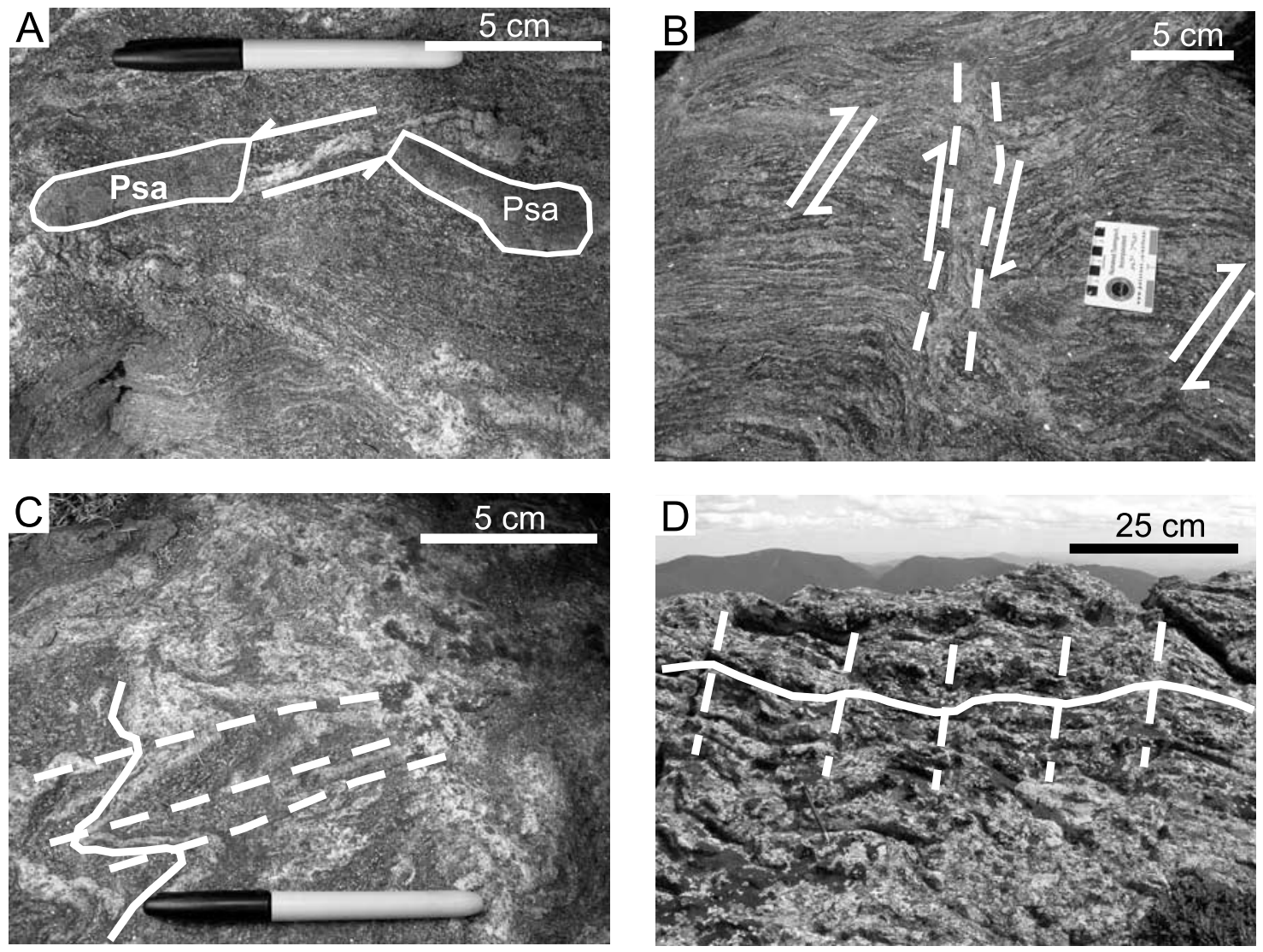

Figure 4. Field photographs showing evidence for metamorphic weakening associated with partial melting. (a) Boudined psammite layer in a migmatitic matrix. The boudinaging of psammitic layers suggests that these layers were weak relative to the leucosome-rich pelitic unit. (b) Leucosome-filled shear zone. (c) Tight shear folds in migmatite. (d) Open folds in unmigmatized units. These folds developed synchronously with the high-strain features in the migmatite, suggesting that the migmatite unit was weak relative to unmigmatized units.

amplitude, long wavelength open folds with east-west trending fold axes (Figure 4d), which record very low strains. In our field area, migmatites occur over an approximately $100 \mathrm{~km}^{2}$ area, and on a regional scale, migmatites of the same age outcrop over an approximately $5000 \mathrm{~km}^{2}$ region [e.g., Guidotti, 1989; Allen, 1992; Brown and Solar, 1998].

[15] The above observations allowed qualitative mechanical stratigraphic sections to be constructed for each deformation for a portion of the Presidential Range area (Figure 5). For the purposes of constructing these qualitative sections, we took the metapsammitic layers as baseline strength and compare the relative strength of the metapelitic layers to this baseline. We consider this to be a valid approach because the mineralogy of the metapsammite layers does not change appreciably during prograde metamorphism. Processes such as grain coarsening during prograde metamorphism, grain size reduction during deformation, or strain hardening could have occurred in the metapsammite layers, each of which would have affected the absolute strength of these layers [e.g., Bons and Cox, 1994; Passchier and Trouw, 1996; De Bresser et al., 2001; Stunitz and Tullis, 2001; Madec et al.,
2003]. However, we are primarily concerned with the relative strength of metapelite and metapsammite layers, with the absolute strength being of secondary concern. Comparing the mechanical stratigraphic sections during each deformation shows that some regions weakened significantly between the deformations, whereas others remained fairly constant in strength (Figure 5). The weakened regions correspond to layers dominated by metapelitic beds, reflecting the relative weakening associated with the pseudomorphing of the andalusite porphyroblasts.

\section{Modeling Environment, Constitutive Relationships and Material Properties}

[16] The problem domain for this series of models is a $450 \times 400 \mathrm{~km}$ crustal block with a thickness of $50 \mathrm{~km}$ (Figure 6). The models provide information about the velocity, displacement and strain fields within the problem domain and we present the deformation field in terms of strain rate. The models consist of an upper crust described by a pressure-dependent plasticity constitutive relationship (Mohr-Coulomb) and a lower crust described by a temper- 


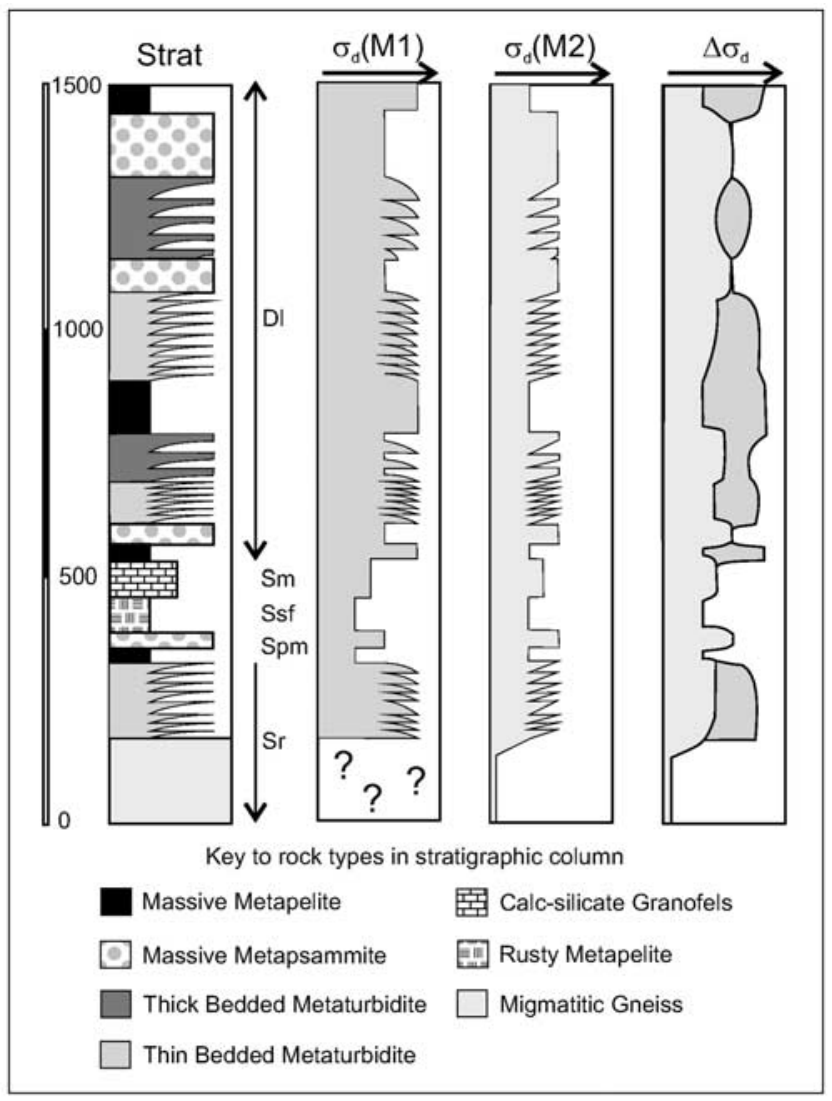

Figure 5. Schematic mechanical stratigraphic column for the study area during metamorphic strengthening and weakening. Left: Stratigraphic column for the study area $(\mathrm{Sr}=$ Silurian Rangeley Formation, $\mathrm{Spm}=$ Silurian Perry Mountain Formation, Ssf $=$ Silurian Smalls Falls Formation, $\mathrm{Sm}=$ Silurian Madrid Formation, $\mathrm{Dl}=$ Devonian Littleton Formation) (Modified from Eusden et al. [1996]). Middle: Idealized mechanical stratigraphic succession illustrating the relative strengths of different units in the study area during early deformation (during andalusite-grade metamorphism) and later deformation (during sillimanite-grade metamorphism and migmatization). Right: Difference in relative strength between the two deformation/metamorphic events.

ature-dependent plasticity constitutive relationship (DruckerPrager) broadly constrained by empirical flow law data for wet quartzite [Hirth et al., 2001, Figure 6]. We test the sensitivity of the position of the zone of strengthening/ weakening and the magnitude of strengthening/weakening. We do not take into account the effects of erosion or sedimentation in these models, although in nature they probably play an important role in the dynamics of a collisional orogen [e.g., Koons, 1990; Willet et al., 2003; Zeitler et al., 1993; Koons et al., 2002; Wobus et al., 2003; Hodges et al., 2004], and we address these in a qualitative manner below.

\subsection{Modeling Environment}

[17] Three-dimensional orogen-scale models were developed using the numerical code FLAC $^{3 \mathrm{D}}$, which we have modified to accommodate large strains [e.g., Koons et al., 2002; Upton et al., 2003; Johnson et al., 2004; Groome et $a l ., 2006]$. Materials in the models are represented by polyhedral elements within a three-dimensional grid using an explicit, time-marching solution and a form of dynamic relaxation. Each element responds according to a prescribed linear or non-linear stress-strain law in response to applied forces or kinematic boundary conditions. The pressuredependent strength of the upper crust in our models is based on the Mohr-Coulomb constitutive relationship:

$$
\sigma_{c}=\sigma_{n} \tan \phi+C
$$

where $\sigma_{c}$ is the failure shear stress, $\sigma_{n}$ is the normal stress, $\phi$ is the internal angle of friction and $C$ is cohesion. The models presented here have a $10 \mathrm{~km}$ thick upper crust, the strength of which is described by equation 2 . The relatively thin Mohr-Coulomb upper crust was used to simulate the effects of an elevated geothermal gradient, which would decrease the depth to the brittle-ductile transition. The temperature-dependent strength of the middle and lower crust is based on the Von Mises failure criterion:

$$
\begin{aligned}
& K_{\phi}=\frac{2}{\sqrt{3}} \sigma_{C} \\
& \sigma_{c}=\left[\left(\frac{\dot{\varepsilon}}{A f_{H_{2} O} O}\right) \operatorname{EXP}\left(\frac{Q}{R T}\right)\right]^{\frac{1}{n}}
\end{aligned}
$$

where $K_{\phi}$ is the shear strength of the material, $\dot{\varepsilon}$ is the shear strain rate, $A$ is the pre-exponential constant, $f_{H 2 O}$ is the water fugacity, $Q$ is the activation energy, $R$ is the gas constant, $T$ is the temperature $(\mathrm{K})$ and $n$ is the stress exponent. Temperature-dependent weakening is modeled by decreasing the value of $K_{\phi}$ with increasing temperature broadly consistent with yield stress data for wet quartzite [Hirth et al., 2001] (see Figure 6 for parameters). The postfailure flow law for both the upper and lower crust is a linear viscous relationship.

\subsection{Material Properties}

[18] We test four strength conditions, relative to the surrounding crust, for the zone of metamorphic strengthening/ weakening: four times stronger, two times stronger, one half as strong and one tenth as strong. The two model groups with a strong zone test an end-member strengthening condition (four times stronger) and a more moderate change in bulk strength (two times stronger). Once the zone is greater than four times stronger than the background crust, our sensitivity analysis suggests that the yield stress is sufficiently high that the zone behaves elastically. We use this condition to model an extreme degree of strengthening associated with metamorphism. We consider the condition that the zone is twice as strong as the surrounding crust to be more realistic, based on our field example where the bulk strengthening associated with porphryblast growth was on 


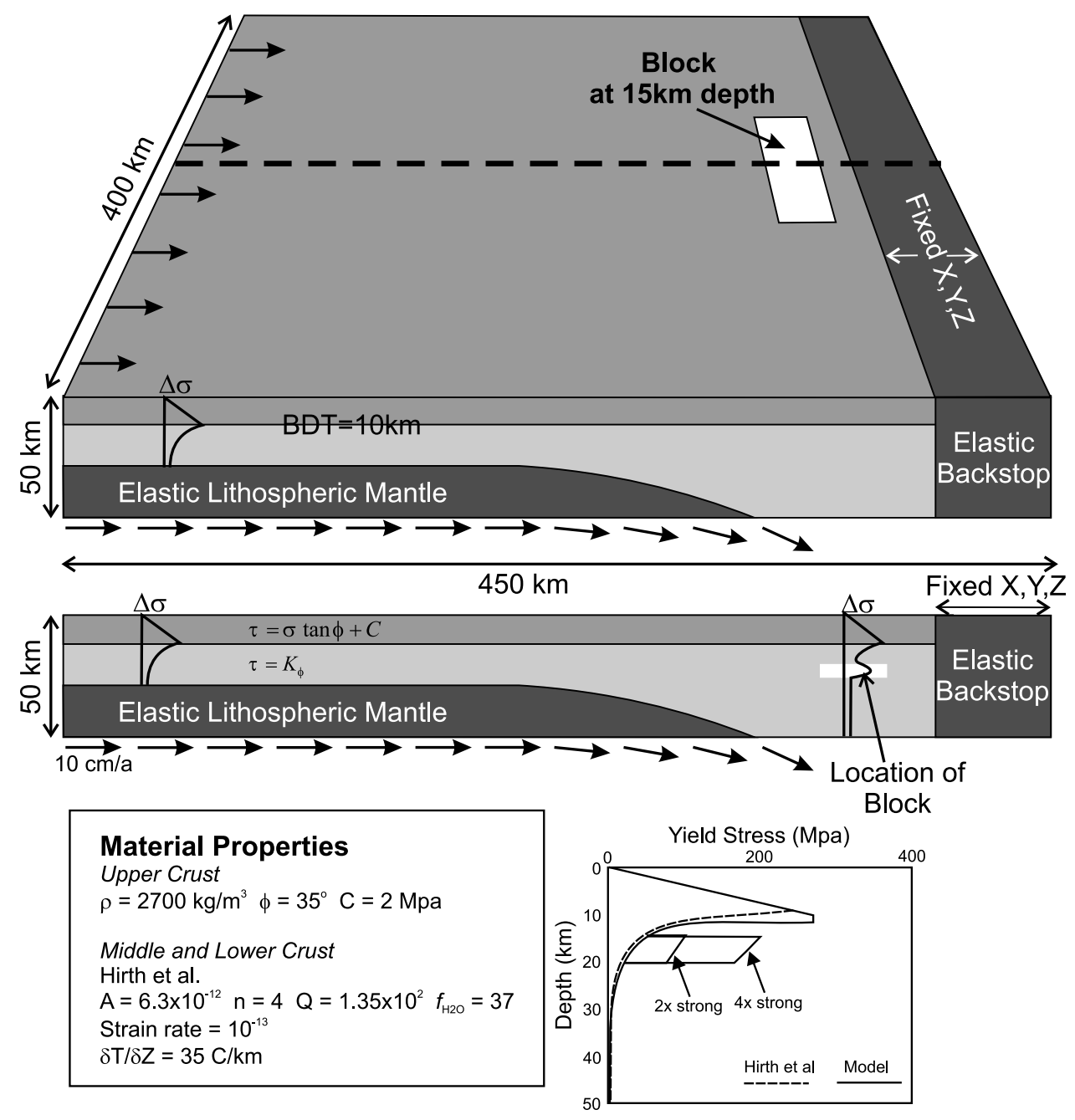

Outboard Geometry
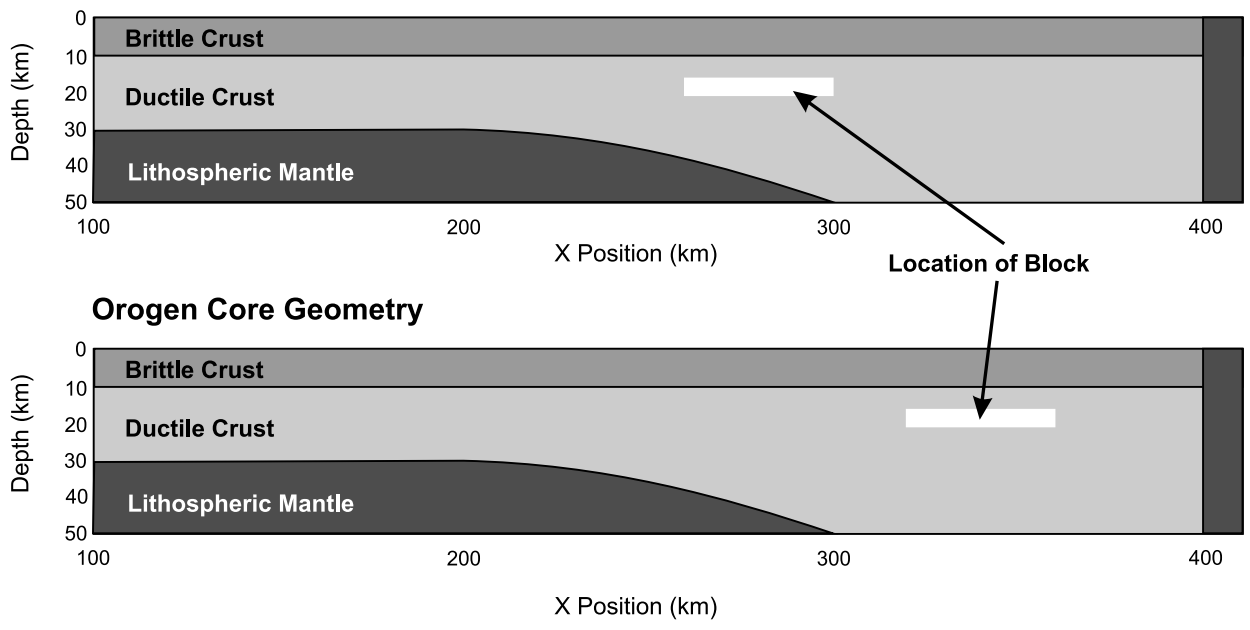

Figure 6. Sketch of the model domain showing the mechanical layering and kinematic boundary conditions. Also shown are the material properties used to describe the strength of the orogen lithosphere and a comparison between the yield stresses used in this model and those derived from the flow law of Hirth et al. [2001]. See text for discussion of the flow laws used. Bottom: The two model geometries presented in this paper are shown. 

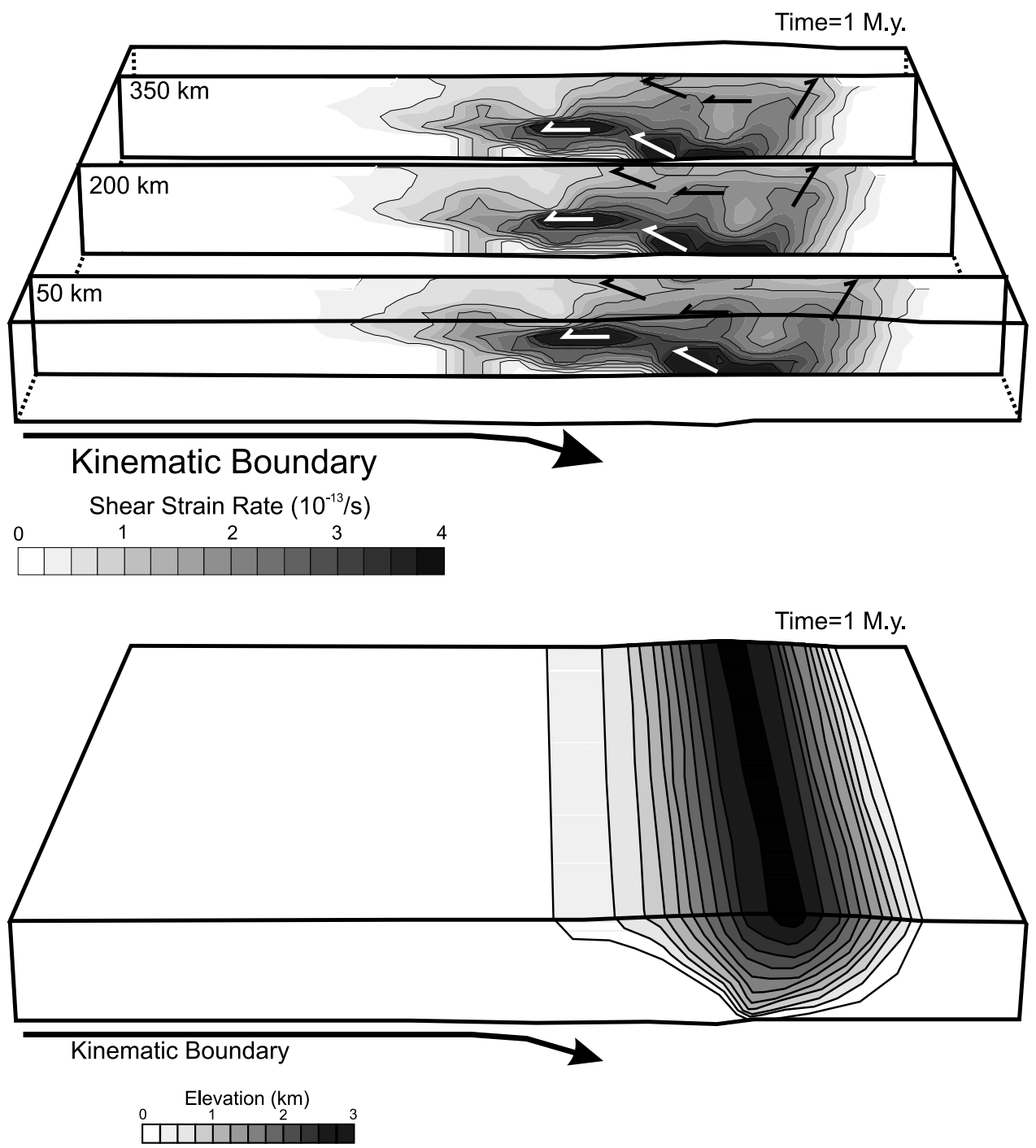

Figure 7. Reference model results at 1 million years since the onset of convergence. Top: Stacked cross-sections of the shear strain rate at 50, 200 and $350 \mathrm{~km}$ in the model domain. Shear sense indicators show the sense of shear as well as interpreted high-strain rate zones developed in the model. Note that only one half of the shear couple is shown for simplicity. Bottom: Reference model topography. Contour interval $=250 \mathrm{~m}$.

the order of two to three times [e.g., Groome and Johnson, 2006].

[19] The models with a zone weaker than the surrounding crust are used to assess the effects of weakening in general, and we do not make any genetic interpretations for the weakening mechanism, except that we infer large degrees of weakening are associated with partial melting [e.g., Arzi, 1978; Paquet et al., 1981, 2005; Hollister and Crawford, 1986; Vigneresse et al., 1996; Mecklenburgh and Rutter, 2003; Takeda and Obata, 2003]. Moderate degrees of weakening (one half the strength of the surrounding crust) could be caused by by elevated pore pressures [e.g., Hubbert and Rubey, 1959; Fyfe, 1985; Cobbold and Castro, 1999; Sibson, 2004], increased fluid content enhancing diffusion rates (i.e., switching the dominant deformation mechanism from dislocation to diffusion creep) [e.g., Farver and Yund, 1999, 2000; De Bresser et al., 2001], or via metamorphism producing relatively weak product minerals [e.g., Rubie, 1983; Koons et al., 1987]. Larger degrees of weakening (one tenth as strong as the surrounding crust) would probably be related to zones of partial melting [e.g., Arzi, 1978; Takeda and Obata, 2003].

\section{Numerical Models}

[20] Two groups of models have been completed, one exploring the effects of strengthening and one the effects of 

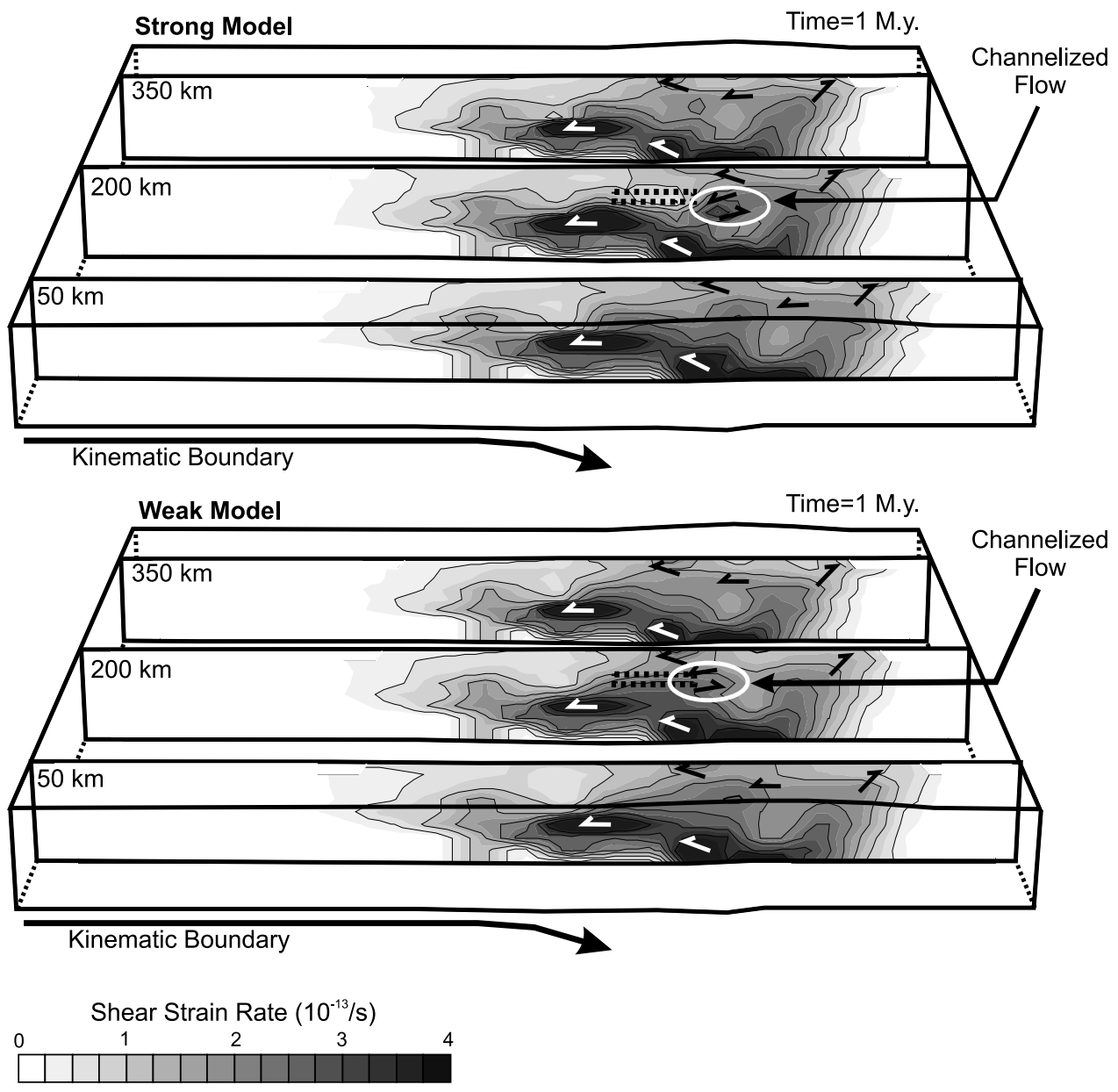

Figure 8a. Shear strain rate contours on stacked cross-sections for the models with strengthening (top) and weakening (bottom) in the outboard part of the orogen. The location of the strengthened and weakened block is shown by the dotted box. Strengthening and weakening is localized in the central part of the model and only significantly affect the $200 \mathrm{~km}$ section. Note the along-strike variability in strain rate distribution evident in the 350 and $50 \mathrm{~km}$ cross-sections (regions unaffected by strengthening/weakening). Also note the change in shear sense as a function of strain rate partitioning in both models.

weakening within the middle and lower crust. The following parameters are investigated: 1) lateral position of the zone of strengthening/weakening within the orogen, and 2) the magnitude of the strength contrast between the heterogeneity and the surrounding crust. We test the sensitivity of model results on lateral position within the orogen because strengthening or weakening metamorphic reactions need not occur just in the core of the orogen, although that is the case in our field example. We consider the magnitude of strengthening/weakening to be an important factor as well because of the inherent uncertainties regarding the degree of strengthening/weakening during metamorphism. We investigate the sensitivity of strain rate distribution and topographic uplift as a function of these parameters. For the sake of brevity, we present the results for two lateral positions, at the orogen toe (outboard region) and $45 \mathrm{~km}$ from the orogen toe (orogenic core), at a depth of 15-20 km
(Figure 6). The two geometries we present show the largest divergence from one-another and intermediate lateral positions have results intermediate between the two end-members. We focus the discussion on the resulting strain rate distribution and topography and quantify the divergence of the model result from a reference model. All results present the model state after approximately $10 \mathrm{~km}$ of plate-normal convergence, equal to approximately $1 \mathrm{Ma}$ of convergence, by which time the orogen model has achieved a steady state strain rate distribution.

\subsection{Reference Model Results}

[21] A reference model is used for comparison with the other models (Figure 7). Collision results in the formation of a two-sided orogenic wedge bounded by crustal-scale high strain rate zones, similar to models described by Koons [1990] and Willet et al. [2003]. In this model reference 

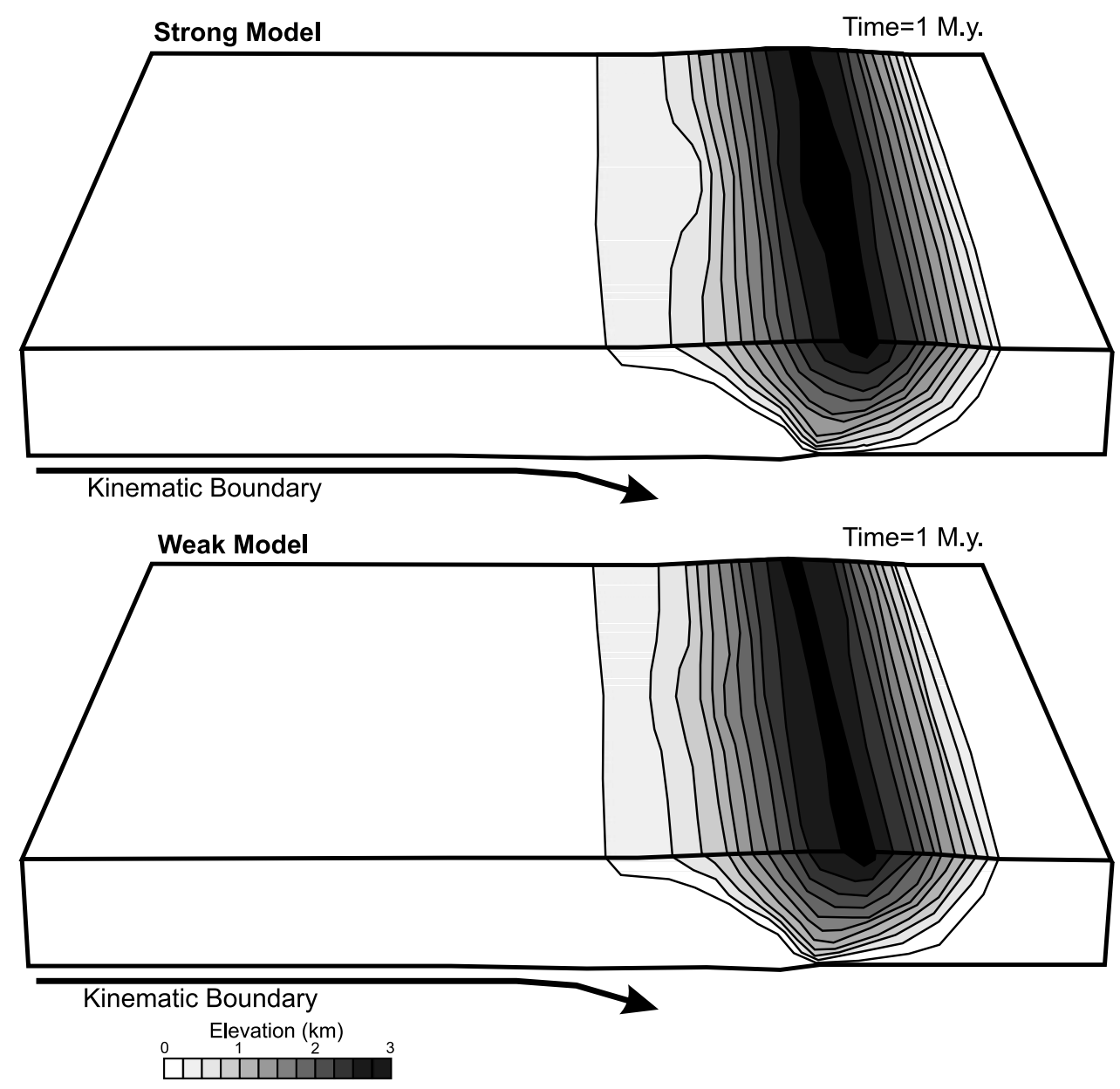

Figure 8b. Model topographies for the outboard geometry models. Top: Strengthening leads to the development of a zone of suppressed topographic uplift above the strong zone. Bottom: Weakening leads to the development of a zone of enhanced topographic uplift above the weak zone. Note that in both models, the zones of strengthening/weakening are restricted in the Y-direction and the topographic effects are localized around the strong and weak zones.

frame, the toe of the orogen is constrained by a top-to-theleft reverse high strain rate zone and the inboard wedge is constrained by a top-to-the-right reverse high strain rate zone. Top-to-the-left high strain rate zones also develop at the base of the model crust in the downgoing plate at the interface between subducting lithospheric mantle and overlying crust. These structures are similar to those found in previous numerical and analogue models [e.g., Koons, 1990; Willet et al., 2003]. The topography of the orogenic wedge is homogeneous, with an outboard slope of approximately 0.3 degrees, and a slightly steeper inboard slope of 0.5 degrees (Figure 7). Topographic uplift is highest in the core of the orogen, and there is a decrease in uplift away from the orogen core. Maximum uplift in the reference model is approximately $2800 \mathrm{~m}$.

\subsection{Strong Zone Model Results}

[22] All models with a strengthened zone have diverged from the reference model in strain rate partitioning, topogra- phy and extent and position of maximum uplift (Figures 8 and 9). All strengthened models have certain features in common, regardless of the magnitude of strengthening or position within the orogen: 1) there is a marked decrease in surface uplift rates immediately above the zone of strengthening; 2) there is an increase in surface uplift rates in the outboard and inboard regions of the zone of strengthening; and 3) high strain rate zones are partitioned around the strengthened zone and a strain rate shadow develops above and behind the strengthened zone. Below, we address the sensitivity of these three factors as a function of the degree of strengthening and the position within the orogen of the strengthened zone.

\subsubsection{Effects of Position}

[23] The position within the orogen where the strengthened zone is located exerts a primary control on both the strain rate partitioning and topographic uplift divergence from the reference model (Figures 8 and 9). All lateral positions result in the formation of high strain rate zones around the strengthened zone, but the magnitude and 

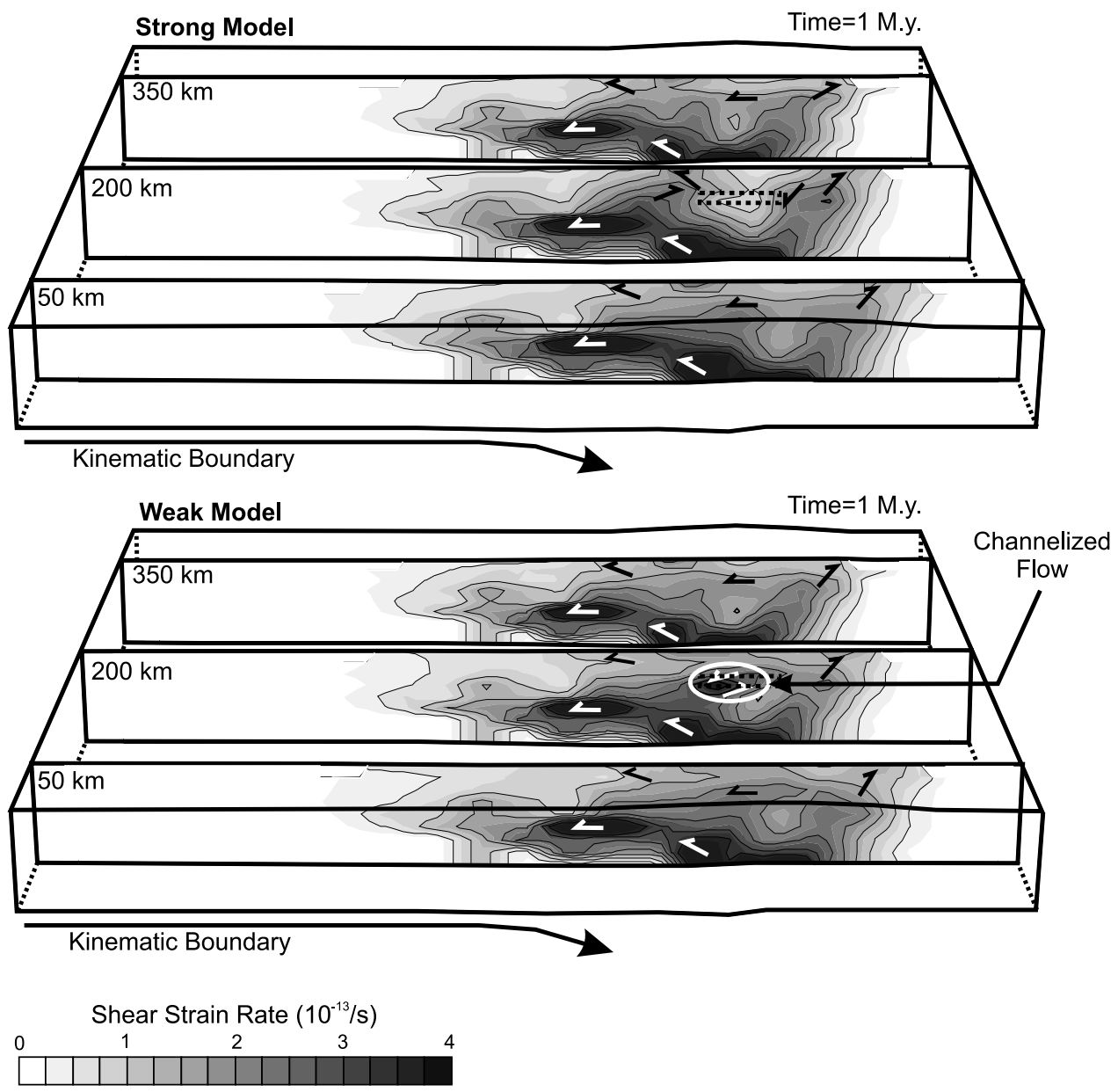

Figure 9a. Shear strain rate contours on stacked cross-sections for the models with strengthening (top) and weakening (bottom) in the core of the orogen. The location of the strengthened and weakened block is shown by the dotted box. Strengthening and weakening is localized in the central part of the model and only significantly affect the $200 \mathrm{~km}$ section. Note the along-strike variability in strain rate distribution evident in the 350 and $50 \mathrm{~km}$ cross-sections (regions unaffected by strengthening/weakening). Also note the change in shear sense as a function of strain rate partitioning in both models.

orientation in these zones is a function of the lateral position of the strengthened zone. Toward the toe of the orogen, strengthening causes the orogen-bounding high strain rate zone to shift toward the core of the orogen, resulting in a decrease in width of the orogen (Figure 8a). The orogenbounding high strain rate zone develops above and behind the strong zone and becomes steeper than the orogenbounding high strain rate zone in the reference model. Below the strengthened zone, a zone of "channel flow" develops, in which the sense of vorticity changes from top to bottom. At the top of this region, a sub-horizontal top-tothe-left normal shear zone develops, but toward the middle of the zone, a top-to-the-right reverse shear zone develops.

[24] Strengthening in the core of the orogen leads to the development of a low-strain rate zone above and behind the strengthened zone, as well as a shift in the position of the orogen-bounding high-strain rate zone (Figure 9a). The orogen-bounding high-strain rate zone originates at the strong zone and is located further to the right in this model than in the reference model. The shifting of the orogenbounding high-strain rate zone results in a narrower orogen than the reference model, but this geometry does not result in as significant a shift in position as the model with strengthening near the orogen toe.

[25] All geometries result in a similar divergence in uplift, with suppressed uplift above the strengthened zone and enhanced uplift along the margins. The enhanced uplift zones also correspond, in general, to zones of elevated strain rate at depth and in some instances at the surface. Strengthening in the core of the orogen leads to the formation of a partially restricted basin bounded by high elevation zones laterally in the orogen and slightly higher topography in front of and behind the basin. Our sensitivity analysis indicates that the depth of the zone of strengthening does not significantly alter the model results, and that the lateral position of the zone of strengthening is much more important. 

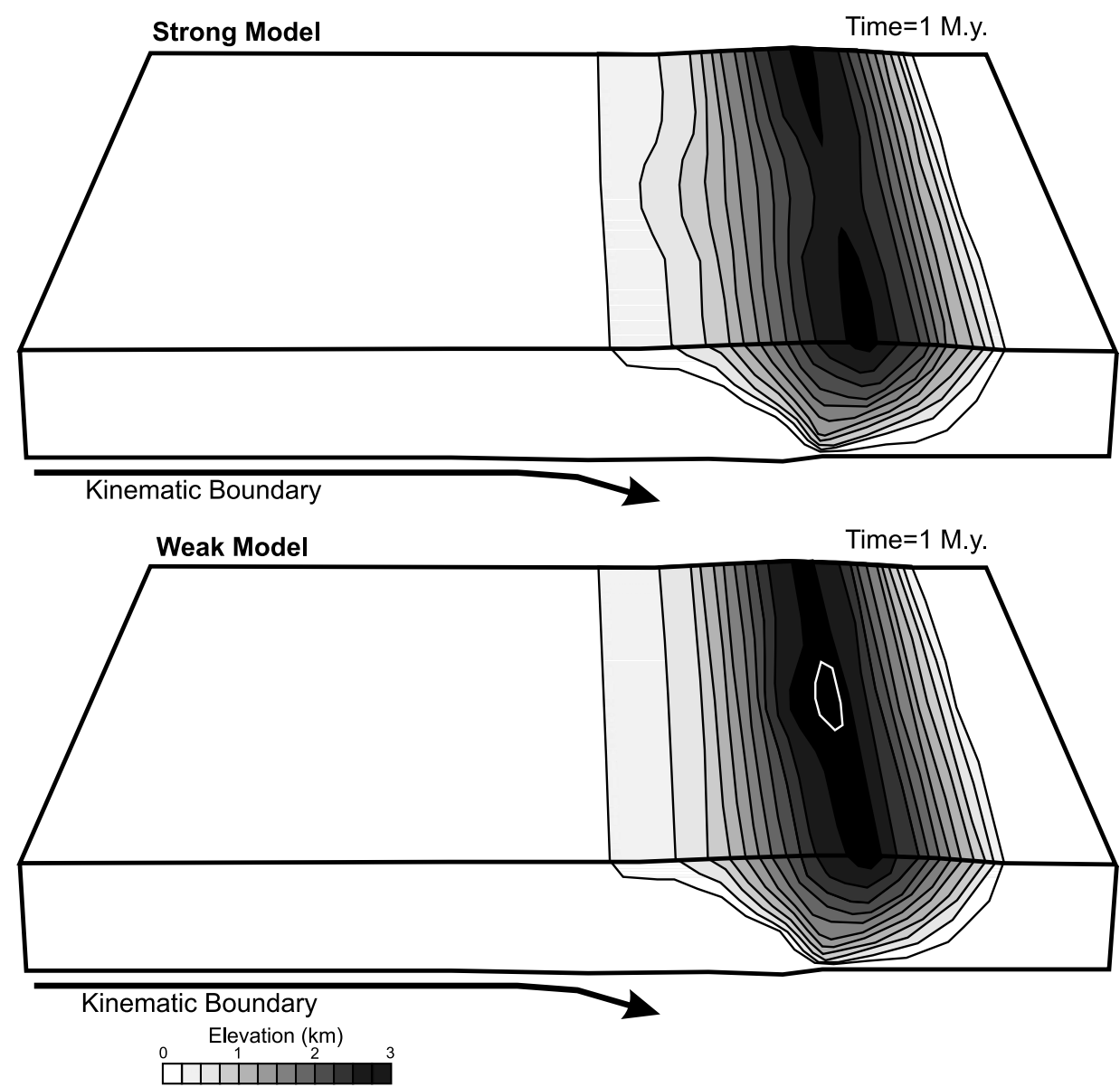

Figure 9b. Model topographies for the orogen core geometry models. Top: Strengthening leads to the development of a zone of suppressed topographic uplift above the strong zone. Bottom: Weakening leads to the development of a zone of enhanced topographic uplift above the weak zone. Note that in both models, the zones of strengthening/weakening are restricted in the Y-direction and the topographic effects are localized around the strong and weak zones.

\subsubsection{Effects of Magnitude of Strengthening}

[26] The model set with the largest strength difference results in the largest divergence from the reference model (Figure 10). Topographic uplift rates are more significantly altered by stronger zones, with a block 4 times stronger than the surrounding crust resulting in uplift rates almost half that in the reference model. However, the difference in topographic uplift rates between models with a block that is twice as strong as the surrounding crust is less than for the model with a block 4 times stronger.

\subsection{Weak Zone Model Results}

[27] All the models with a weakened zone diverge from the reference model in the following ways: 1) a zone of enhanced topographic uplift is formed above the weakened zone, 2) zones of suppressed topographic uplift are variably developed outboard and inboard of the weakened zone, and 3) high strain rate zones are developed within, and low strain rate zones are variably developed along the margins, of the weakened zones. Below, we summarize the sensitivity of these features on the magnitude of weakening and the position of the weakened zone.

\subsubsection{Effects of Position}

[28] As with the zones of strengthening, divergence from the reference model is largely a function of the position within the orogen of the weakened zone (Figures 8 and 9). All positions that we tested resulted in the formation of high strain rate zones associated with the weakened zone, but these zones are better developed if the weakened zone is located in the core of the orogen. Weakening in the outboard part of the orogen does not significantly affect the position of the orogen-bounding high-strain rate zone, but the highstrain rate zone does widen relative to the reference model.

[29] Weakening in the core of the orogen results in the formation of "crustal channels," similar to structures described by Beaumont et al. [2001] [see also Jamieson et al., 2002; Beaumont et al., 2004; Gibson et al., 2005], although the channel zones in our models do not produce the same 
high strain flow as in previous models, we use the term "channel zone" to simply describe the flow field within these regions. These channels are zones of high particle velocity bounded by shear zones having opposite senses of shear: an upper shear zone with a normal shear sense and a lower shear zone with a reverse sense of shear. In the models presented here, the crustal channels are bounded above by top-to-the-left normal shear zones and below by top-to-the-right reverse shear zones. Between these bounding shear zones, a high velocity zone develops in the weakened area that trends toward the inboard orogenbounding shear zone.

[30] All geometries result in the formation of zones of enhanced topographic uplift, with or without related zones of suppressed uplift (Figures 8 and 9). Weakening in the outboard region of the orogen leads to the development of zones of minor suppressed topographic uplift along the margins of the zone of elevated topographic uplift related to the weakened zone. However, weakening in the core or inboard region of the orogen leads to the development of more significant zones of suppressed topographic uplift in the foreland of the weakened zone.

\subsubsection{Effects of Magnitude of Weakening}

[31] In general, greater degrees of weakening lead to greater divergence from the reference model, both in strain rate localization and topographic uplift. The model group with a zone ten times weaker than the surrounding crust has maximum topographic uplift up to $250 \mathrm{~m}$ higher than the reference model above the weakened zone, and variable amounts of suppressed topographic uplift along the periphery of the weakened zone (less than $100 \mathrm{~m}$ ). The model group with a zone half as strong as the surrounding crust has maximum topographic uplifts on the order of $100 \mathrm{~m}$ above the weakened zone and suppressed zones on the order of $50 \mathrm{~m}$ lower along the periphery (Figure 10).

[32] Strain rate localization into the weakened zones is also more prominent in the weaker model group. In the group with a zone one tenth as strong as the surrounding crust, the highest strain rates are up to $50 \%$ greater than in the reference model. In the group with a zone half as strong as the surrounding crust, the maximum increase in strain rates is approximately $20 \%$. Of particular note, in the models with weakening in the core of the orogen, the crustal "channel zones" are much better developed in the weaker model group.

\section{Discussion}

\subsection{Factors not Accounted for in These Models}

[33] In general, these models provide insight into the relationship between changes in rheology associated with metamorphism and the dynamic evolution of an orogen on short timescales $(1 \mathrm{Ma})$. They do, however, neglect certain aspects of orogenesis that may have an important role in orogen dynamics. Of particular note, we do not allow for erosion in these models, which would alter the topographic profile of an orogen, and probably localize exhumation of high-grade rocks into zones of focused erosion [e.g.,
Beaumont et al., 2001, 2004; Koons et al., 2002; Zeitler et al., 1993; Jamieson et al., 2004]. We also do not allow for dynamic rheologic changes, such as those associated with active metamorphic reactions [e.g., Rubie, 1983; Brodie and Rutter, 1987; Koons et al., 1987; Freuh-Green, 1994] or strain weakening in shear zones [e.g., Rutter, 1999; Garlick and Gromet, 2004; De Ronde et al., 2005; Holyoke and Tullis, 2006]. The models only account for large-scale rheologic changes on the million year timescale, but in natural orogens transient weakening and strengthening may also have a significant effect on orogen dynamics [e.g., Handy et al., 2001]. Finally, these models present purely mechanical solutions without associated thermal perturbations, which would influence the location of metamorphism. Despite the limitations noted here, our models do provide insight into the effects of changes in mid-crustal rheology on the dynamics of convergent orogens, as outlined below.

\subsection{Model Implications}

[34] Our models illustrate the effects of localized changes in mid-crustal rheology on orogenesis. There is a strong relationship between changes in mid-crustal rheology and the topographic uplift in an orogenic belt, with strengthened zones resulting in suppressed uplift rates and weakened zones resulting in enhanced uplift rates. The models also show how changes in mid-crustal strength can shift the location of high strain rate zones, which may result in some enigmatic geologic features.

6.2.1. Changes in Topographic Uplift and Implications for the Exhumation of High-Grade Metamorphic Rocks

[35] These models show that strengthened zones in the middle crust lead to suppressed topographic uplift above the strengthened zones. Reduced topographic uplift above the strengthened zones is a manifestation of deformation partitioning around these zones causing enhanced uplift along the periphery of strengthened zones. This effect is the opposite as what is seen in regions of metamorphic weakening, where enhanced uplift is associated with the weak zones. The decrease in topographic uplift associated with metamorphic strengthening would probably lead to a decrease in erosion rates above these zones, and potentially lead to sediment deposition in these areas. If strengthening occurs near the toe of the orogen, strain partitioning in front of the strengthened zone may shift the position of the orogen-bounding shear zone and suppressed uplift above the strengthened zone could lead to the formation of a basin above the strengthened zone that could broadly be described as a piggyback basin [e.g., Ori and Friend, 1984]. In our model, this basin is up to $200 \mathrm{~m}$ lower elevation than a frontal topographic high that separates the basin from the orogen toe.

[36] In our models, strengthening in the core of the orogen results in the formation of a topographic low above the strengthened zone that is flanked by zones of higher elevation and steeper topographic slopes (Figures $8 \mathrm{~b}$ and 9b). The topographic low could broadly be viewed as a partially restricted basin, in that it is flanked by zones of higher elevation parallel to the trend of the orogen but not perpendicular to the orogen. Erosion in the higher elevation 

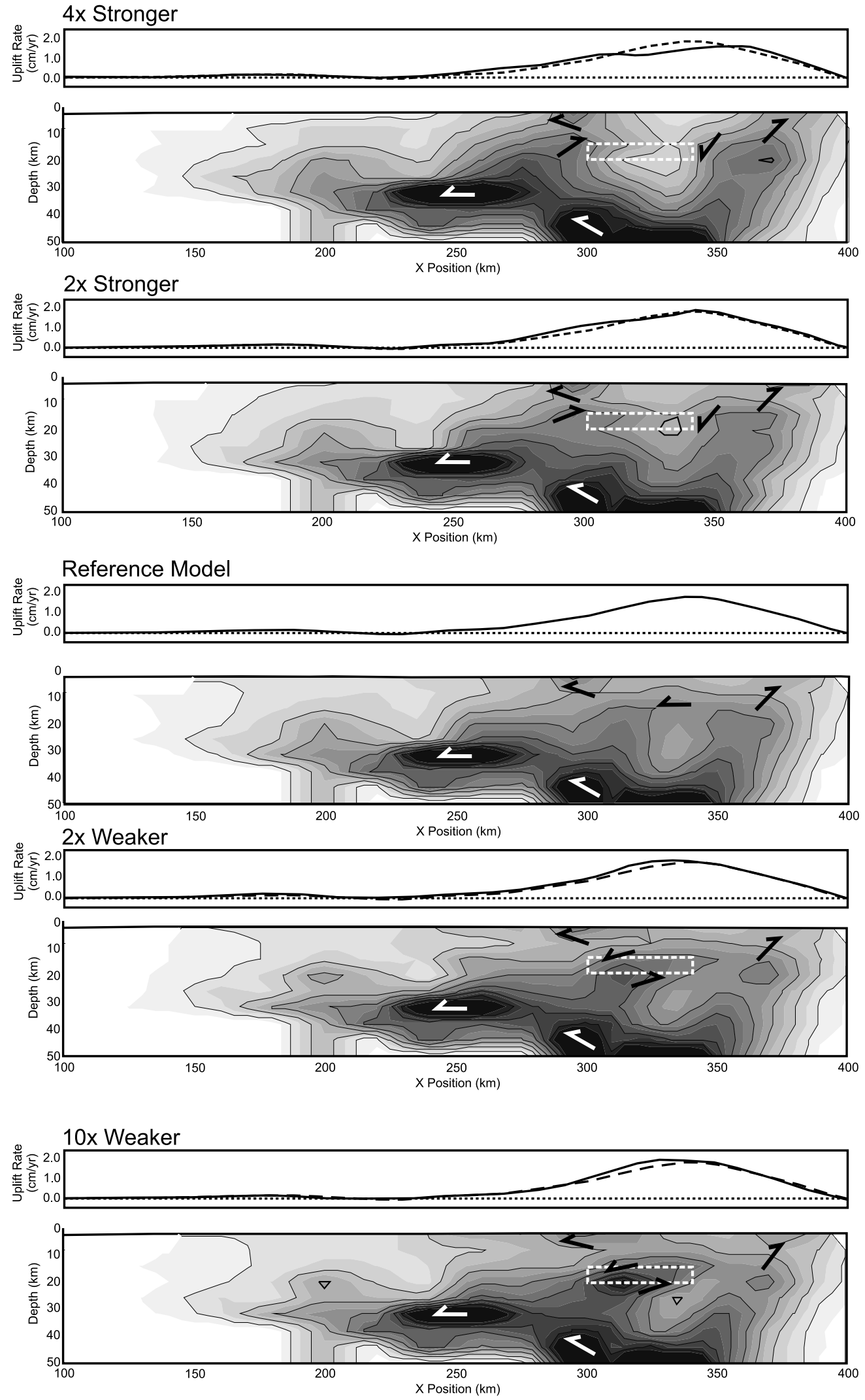

Figure 10. Results for the models with strengthening/weakening in the core of the orogen showing the effects of different strength contrasts between the block and surrounding crust. Cross sections are through the center of the model domain. 
zones could potentially lead to sediment deposition in the topographic depression, which would retard exhumation rates. Conversely, weakening in the core of the orogen leads to the development of an area of higher topography above the weakened zone, the magnitude of which is largely a function of the degree of weakening. If there was a positive feedback between elevation and erosion (as in the Southern Alps or along the southern flank of the Himalaya) the enhanced topographic uplift rate associated with metamorphic weakening could lead to enhanced exhumation rates. Focused exhumation of hot, weak rocks would lead to focused crustal weakening because the depth to the brittle-ductile transition would be altered, which would in turn lead to further focusing of exhumation and erosion [e.g., Zeitler et al., 1993; Jamieson et al., 2002; Koons et al., 2002].

6.2.2. Metamorphism, Shifting Strain Rate Localization and Deformation Kinematic Partitioning

[37] Changes in mid-crustal rheology in our models also result in a redistribution of relatively high and low strain rate zones, as well as changes in the recorded deformation kinematics at certain parts of the orogen. The changes in deformation kinematics recorded in our models provide potential insight into the poly deformational history of low-pressure, high-temperature metamorphic belts.

[38] In our reference model, without any strengthened our weakened zones, we recognize three principal structural regimes based on flow kinematics (Figure 7). In the outboard part of the orogen, flow kinematics suggest gently dipping, top-to-the-foreland reverse structures should dominate (including thrust faults/shear zones, asymmetric folds verging toward the orogen toe, and shear sense indicators in the rocks recording this sense of motion). The outboard structural regime changes into one that records subhorizontal, top-to-the-foreland deformation kinematics in the core of the orogen at depth. In this structural regime, the deformation kinematics continue to record the same sense of motion as in the outboard part of the orogen, but the primary difference is the dip of the structures (here they are flatlying, whereas in the outboard part of the orogen they dip gently toward the core of the orogen). Inboard of the orogen core, a third structural regime preserving relatively steeply dipping top-to-the-hinterland reverse shear sense is developed. These three structural regimes are similar to those observed in previous studies of two-sided orogens [e.g., Koons, 1990; Willet et al., 2003; Beaumont et al., 1996; Koons et al., 2003b].

[39] As parts of the orogen strengthen and weaken during metamorphism, strain rates partition into the relatively weak region, i.e., strengthening results in strain rate partitioning out of the strengthened region and weakening results in strain rate partitioning into the weakened zone. In addition to the shifting of strain rates, the kinematics of flow are also affected by strengthening and weakening, which results in different structural regimes being developed than in an orogen without strengthened/weakened regions. The effects of both strain rate partitioning and changes in deformation kinematics within the orogen are strongly dependent on the location of strengthening and weakening. To assess the importance of strengthening/weakening location on the resulting strain rate and deformation partitioning within the orogen, we investigate the detailed kinematics of our outboard and orogen core models.

[40] In the outboard part of the orogen, strengthening causes two major structural changes relative to the reference model. The first major structural shift occurs above and inboard of the strong zone, where the orogen-bounding shear zone becomes steeper as it climbs up and over the strong zone. In a natural orogen, this should lead to the development of steeper shear zone fabrics, which could overprint earlier-formed fabrics developed prior to strengthening. The second feature is the development of a crustal channel below and inboard of the strong zone. From top to bottom, this zone records alternating senses of shear: at the top, top-to-the-foreland normal shear zones dominate, in the middle of the zone, top-to-the-hinterland reverse shear zones dominate, and at the bottom of the zone, top-to-theforeland normal shear zones dominate. This channel zone trends toward the inboard orogen-bounding shear zone, and toward a zone of elevated topographic uplift rates. In a natural orogen, the development of this zone could lead to the formation of sub-horizontal shear fabrics that may record changing shear sense indicators, overprinting older, steeper shear fabrics.

[41] In the outboard part of the orogen, weakening leads to the development of a broad zone of relatively high shear-strain rates above the weakened zone, associated with increased topographic uplift rates (Figures $8 \mathrm{a}$ and $8 \mathrm{~b}$ ). Shear-strain rates are highest toward the inboard part of the weakened block. Below and inboard of the weakened zone a crustal channel zone develops in which the sense of shear changes from top to bottom, similar to the channel zone developed in the model with a strong zone in the outboard region. However, the channel zone in the weakened model is not as well developed as in the model with a strong zone.

[42] In the core of the orogen, strengthening causes two major shifts in strain rate localization, relative to the reference model. Outboard of the strong block, the orogen-bounding shear zone becomes shallower, and narrower, than in the reference model (Figures 9a and 9b). A zone of steeper reverse shear also develops slightly inboard and above the strong zone. Compared with the reference model, these two shear zones define a much narrower zone of top-to-theforeland reverse shear near the toe of the orogen. The second major structural shift occurs above and inboard of the strong zone, where a low-strain rate zone develops. In a natural orogen, the development of this low strain zone would cause any shear zones in this region to become inactive after strengthening at deeper crustal levels.

[43] In the core of the orogen, weakening leads to the development of a prominent crustal channel through the middle of the weakened zone. This channel zone records a reversal in shear sense from top to bottom and trends toward the inboard orogen-bounding shear zone. Above and outboard of the weakened zone, a zone of top-to-the-foreland 
reverse shear develops with higher strain rates than in the reference model.

\subsubsection{Changing Deformation Kinematics and Complex Overprinting Structures}

[44] Shifting strain rate localization resulting from metamorphic strengthening and weakening in our models suggest that structures in polymetamorphic terranes may have complex overprinting relationships. Sequential strengthening and weakening will cause strain to partition into different parts of the orogen, and may lead to a reversal in shear sense in certain parts of the orogen. As examples of this process, we investigate the shifting deformation kinematics at a location in the core of the orogen as a function of metamorphic strengthening and weakening at two different parts of the orogen.

[45] The first example considers overprinting structures in a rock unit from the core of an orogen that experienced metamorphic strengthening and weakening in the outboard region of the orogen (Figure 11). In the reference model, this rock would be located in a region of top-to-the-foreland reverse shear, and would preserve gently dipping, top-tothe-foreland shear sense indicators (Figure 11a). Metamorphic strengthening in the outboard region of the orogen causes the sense of shear to change for our hypothetical rock (Figure 11b). The rock would be located in a region dominated by top-to-the-foreland normal shear, and would preserve shear sense indicators suggesting extension. Metamorphic weakening in the outboard region of the orogen would lead to yet another change in shear sense in our hypothetical rock (Figure 11d). The rock would now be located in a region dominated by top-to-the-hinterland reverse shear, and preserved structures would record the opposite sense of shear as in the reference model. In this example, the hypothetical rock is located outside the zone of metamorphic strengthening or weakening, and may not record strengthening or weakening reactions.

[46] If sequential strengthening and weakening were to occur in the outboard part of the orogen, a rock in the orogen core may preserve structures that, in order, preserve top-to-the-foreland reverse shear, top-to-the-hinterland normal shear and top-to-the-hinterland reverse shear. Geologically, one may conclude the following geologic history: early right-directed subduction followed by orogenic extension finally overprinted by a reversal in subduction polarity. However, in our model, these overprinting structures could be developed by sequential strengthening and weakening outside the region of study in the orogen core, without any change in far-field plate kinematics.
[47] In our second example, we consider the effects of metamorphic strengthening and weakening in the core of the orogen on the inferred kinematics of our hypothetical rock. Once again, the reference model conditions would result in the formation of top-to-the-foreland reverse shear fabrics. Metamorphic strengthening would lead to a reduction in strain rates where our rock is located (Figure 11c). This could result in the preservation of low-strain structures overprinting earlier higher strain structures, accompanied by low-pressure metamorphism. Metamorphic weakening would lead to strain partitioning into the region where our hypothetical rock is located (Figure 11e). Depending on the region one would be working in, one may observe a change in shear sense from top to bottom of the weakened zone. Toward the top of the weakened zone, top-to-the-foreland normal shear sense indicators would be developed, whereas toward the bottom of the weakened zone, top-to-thehinterland reverse shear sense indicators would develop (Figure 11e).

[48] If sequential strengthening and weakening occurs in the core of the orogen, a rock could preserve structures that, in sequential order, preserve top-to-the-foreland reverse shear fabrics, a period of low strain deformation, and either top-to-the-foreland extensional fabrics or top-to-the-hinterland reverse shear fabrics depending on where in the weakened zone the rock was deformed. Geologically, one may conclude the following sequence of events: early rightdirected subduction, followed by a phase of tectonic quiescence overprinted by any one of 1) orogenic collapse, 2) subduction polarity reversal or 3) channel flow through the migmatite terrane.

\section{Conclusions}

[49] Changes in mid-crustal strength resulting from metamorphic strengthening and weakening probably play an important role in the dynamic evolution of an orogen. Our three-dimensional models indicate that the primary controls on changes in orogen dynamics associated with changes in mid-crustal strength are the lateral position in the orogen (how far the zone is from the toe of the orogen) and the magnitude of strengthening/weakening. In general metamorphic strengthening has the following effects: 1) zones of suppressed topographic uplift develop above the strengthened zone, 2) zones of enhanced topographic uplift develop in front of and behind the strengthened zone, and 3 ) the development of high-strain rate zones around the strong blocks, with differing deformation kinematics

\footnotetext{
Figure 11. Strain rate contour maps and hypothetical fabrics formed in a rock from the core of the orogen. (a) Reference model results. Fabrics developed in the hypothetical rock should be moderately dipping and record top-to-the-left reverse shear sense indicators. (b) Results with a strong block in the outboard part of the orogen. Fabrics in the hypothetical rock should be moderately dipping and record top-to-the-right reverse shear sense indicators. (c) Results with a weak block in the outboard part of the orogen. Fabrics should be gently dipping and record top-to-the-left normal shear sense indicators. (d) Results with a strong block in the core of the orogen. Low-strain structures should be preserved in this situation. (e) Results with a weak block in the core of the orogen. Structures should be gently dipping and record a change in shear sense from top-to-the-left normal shear near the top to top-to-the-right reverse shear toward the bottom. Note that in all cross-sections, the dashed lines delineate regions of differing flow vorticity.
} 


\section{Reference}
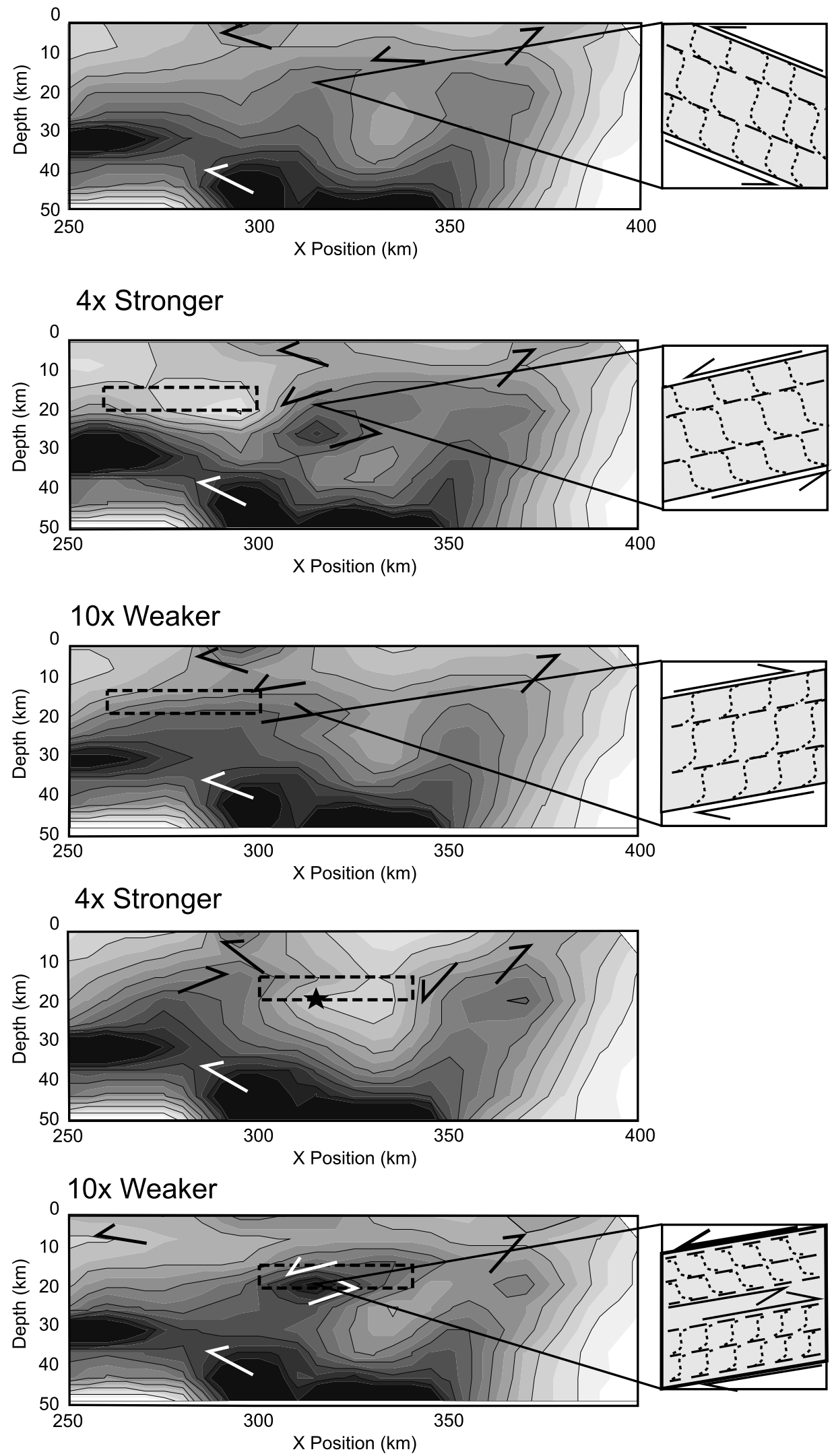

Figure 11 
depending on where in the orogen strengthening occurs. Metamorphic weakening has the following effects: 1) zones of enhanced topographic uplift develop above the weakened zone, 2) zones of suppressed topographic uplift are variably developed in front of and behind the weakened zone, and 3) shear zones develop at the top and bottom of the weakened zone, with opposite senses of shear, which results in the formation of a crustal channel within the weakened zone.

[50] We further suggest that some enigmatic geologic features preserved in many orogens may owe their existence to strain partitioning associated with changes in mid-crustal strength. First, piggyback basins developing at the toe of an orogenic wedge may develop above relatively strong zones in the middle crust, and may not necessarily result from thin-skinned tectonic processes. Second, kinematic indica- tors suggesting reversals in the mid- to upper-crustal flow field through time are not necessarily associated with changes in large-scale plate kinematics, but may be a result of shifting strain rate distribution associated with metamorphic strengthening and weakening.

[51] Acknowledgments. Financial support came from grant NSF EAR 0207717 (to SEJ and POK), the Geological Society of America Grants in Aid Program (to WGG) and a Maine Economic Improvement Fund Graduate Fellowship (to WGG). We thank Dyk Eusden for introducing us to the geology of the White Mountains region, Malissa Washburn for field assistance, and the US Forest Service Androscoggin Ranger Station, the Appalachian Mountain Club and the Mt. Washington Auto Road for logistical support in the field. Constructive reviews by Caleb Holyoke, Rebecca Jamieson and Keith Klepeis improved the quality of this manuscript. We dedicate this paper to Charlie Guidotti.

\section{References}

Allen, T. T. (1992), Migmatite systematics and geology, Carter Dome-Wild River region, White Mountains, New Hampshire, PhD Thesis, Dartmouth College, Hanover, N. H.

Allen, T. T. (1996), Stratigraphic and structural traverse of Mt. Moriah, New Hampshire. New England Inter-Collegiate Geology Conference Field Guide for field trips in northern New Hampshire and adjacent regions of Maine and Vermont, 155-169.

Allis, R. G., R. W. Henley, and A. F. Carman (1979), The thermal regime beneath the Southern Alps, Bull. R. Soc. N. Z., 108, 79-85.

Arzi, A. A. (1978), Critical phenomena in the rheology of partially melted rocks, Tectonophysics, 44, 173 184.

Axen, G. J., J. Selverstone, and T. Wawrzyniec (2001), High-temperature embrittlement of extensional Alpine mylonite zones in the midcrustal ductilebrittle transition, J. Geophys. Res., 106, 4337-4348.

Babeyko, A., S. V. Sobolev, R. B. Trumbull, O. Oncken, and L. L. Lavier (2002), Numerical models of crustal scale convection and partial melting beneath the Altiplano-Puna Plateau, Earth Planet. Sci. Lett., 119, 373-388.

Barnes, J. D., J. Selverstone, and Z. D. Sharp (2004), Interactions between serpentinite devolatization, metasomatism and strike-slip strain localization during deep-crustal shearing in the Eastern Alps, J. Metamorph. Geol., 22, 283-300.

Barraud, J., V. Gardien, P. Allemand, and P. Grandjean (2001), Analogue modeling of melt segregation and migration during deformation, Phys. Chem. Earth (A), 26, 317-323.

Barton, M. D., and R. B. Hanson (1989), Magmatism and the development of low-pressure metamorphic belts: Implications from the western United States and thermal modeling, GSA Bulletin, 101, 10511065.

Bauer, P., S. Palm, and M. R. Handy (2000), Strain localization and fluid pathways in mylonite: Inferences from in situ deformation of a water-bearing quartz analogue (norcamphor), Tectonophysics, $320,141-165$.

Beaumont, C., S. Ellis, J. Hamilton, and P. Fullsack (1996), Mechanical model for subduction-collision tectonics of alpine-type compressional orogens, Geology, 24, 675-678.

Beaumont, C., R. A. Jamieson, M. H. Nguyen, and B. Lee (2001), Himalayan tectonics explained by extrusion of a low-viscosity crustal channel coupled to focused surface denudation, Nature, 414, 738-742.

Beaumont, C., R. A. Jamieson, M. H. Nguyen, and S. Medvedev (2004), Crustal channel flows 1: Numerical models with applications to the tectonics of the Himalayan-Tibetean orogen, J. Geophys. Res., 109, B06406, doi:10.1029/2003JB002809.
Billings, M. P., C. A. Chapman, R. W. Chapman, K. Fowler-Billings, and F. B. Loomis Jr. (1946) Geology of the Mt. Washington quadrangle, New Hampshire, GSA Bulletin, 57, 261 - 274.

Bons, P. D., and S. J. D. Cox (1994), Analogue experiments and numerical modeling on the relation between microgeometry and flow properties of polyphase materials, Mater. Sci. Eng., A175, 237-245.

Bradley, D. C., R. D. Tucker, D. R. Lux, A. G. Harris, and D. C. McGregor (2000), Migration of the Acadian Orogen and Foreland Basin across the Northern Appalachians of Maine and adjacent areas, USGS Professional Paper 1624, 64 pp.

Brodie, K. H., and E. H. Rutter (1987), The role of transiently fine-grained reaction products in syntectonic metamorphism: Natural and experimental examples, Can. J. Earth Sci., 24, 556-564.

Brown, M., and G. S. Solar (1998), Shear zones systems and melts: feedback relations and self-organization in orogenic belts, J. Struct. Geol., 20, 211-227.

Carminati, E., and G. B. Siletto (1997), The effects of brittle-plastic transitions in basement-involved foreland belts: The Central Southern Alps case (N. Italy), Tectonophysics, 280, 107-123.

Cobbold, P. R., and L. Castro (1999), Fluid pressure and effective stress in sandbox models, Tectonophysics, 301, 1-19.

Dahlen, F. A., and J. Suppe (1984), Mechanics of foldand-thrust belts and accretionary wedges: Cohesive Coulomb theory, J. Geophys. Res., 89, 10,08710,101

Daniel, C. G., L. S. Hollister, R. R. Parrish, and D. Grujic (2003), Exhumation of the Main Central Thrust from lower crustal depths, Eastern Bhutan Himalaya, J. Metamorph. Petrol., 21, 317-334.

Davis, D., J. Suppe, and F. A. Dahlen (1983), Mechanics of fold-and-thrust belts and accretionary wedges, J. Geophys. Res., 88, 1153-1172.

De Bresser, J. H. P., J. H. Ter Heege, and C. J. Spires (2001), Grain size reduction by dynamic recrystallization: Can it result in major rheologic weakening?, Int. J. Earth Sci., 90, 28-45.

De Ronde, A. A., H. Stunitz, J. Tullis, and R. Heilbronner (2005), Reaction-induced weakening of plagioclaseolivine composites, Tectonophysics, 409, 85-106.

De Yoreo, J. J., D. R. Lux, and C. V. Guidotti (1991), Thermal modeling in low-pressure/high-temperature metamorphic belts, Tectonophysics, 188, 209-238.

England, P., and G. Houseman (1985), Role of lithospheric strength heterogeneities in the tectonics of Tibet and neighboring regions, Nature, 315, 297-301.

Enlow, R. L., and P. O. Koons (1998), Critical wedges in three dimensions: Analytical expressions from Mohr-Coulomb constrained perturbation analysis, J. Geophys. Res., 103, 4897-4914.
Eusden, J. D., J. M. Garesche, A. H. Johnson, J. Maconochie, S. P. Peters, J. B. O'Brien, and B. L. Widmann (1996), Stratigraphy and ductile structure of the Presidential Range, New Hampshire: Tectonic implications for the Acadian Orogeny, GSA Bulletin, $108,417-437$.

Eusden, J. D., C. A. Guzofski, A. C. Robinson, and R. D. Tucker (2000), Timing of the Acadian Orogeny in Northern New Hampshire, J. Geol., 108, 219-232.

Farver, J. R., and R. A. Yund (1999), Oxygen bulk diffusion measurements and TEM characterization of a natural mylonite: Implications for fluid transport in mica-bearing rocks, J. Metamorph. Geol., $17,669-683$.

Farver, J. R., and R. A. Yund (2000), Silicon diffusion in a natural quartz aggregate: Constraints on solution-transfer diffusion creep, Tectonophysics, 325, $193-205$.

Freuh-Green, G. L. (1994), Interdependence of deformation, fluid infiltration and reaction progress recorded in eclogitic metagranitoids (Sesia Zone, Western Alps), J. Metamorph. Geol., 12, 327343 .

Fyfe, W. S. (1985), Fluids, tectonics and crustal deformation, Tectonophysics, 119, 29-36.

Garlick, S. R., and L. P. Gromet (2004), Diffusion creep and partial melting in high-temperature mylonitic gneisses, Hope Valley Shear Zone, New England Appalachians, USA, J. Metamorph. Geol., 22, 45-62.

Gibson, H. D., R. L. Brown, and S. D. Carr (2005), U$\mathrm{Th}-\mathrm{Pb}$ geochronologic constraints on the structural evolution of the Selkirk Fan, northern Selkirk Mountains, southern Canadian Cordillera, J. Struct. Geol., 27, 1899-1924.

Groome, W. G. (2006), The rheologic evolution of the middle crust during prograde metamorphism: Implications for the geodynamic evolution of convergent orogens, PhD Dissertation, Univ. of Maine, Orono, $267 \mathrm{pp}$.

Groome, W. G., and S. E. Johnson (2006), Constraining the relative strengths of high-grade metamorphic rocks using foliation refraction angles: An example from the Northern New England Appalachians, J. Struct. Geol., doi:10.1016/j.jsg.2006.03.023.

Groome, W. G., S. E. Johnson, and P. O. Koons (2006), The effects of porphyroblast growth on the effective viscosity of metapelitic rocks: Implications for the strength of the middle crust, J. Metamorph. Geol., doi:10.1111/j.1525-1314.2006.00644.

Gualteri, L., G. Bertotti, and S. Cloetingh (1998), Lateral variations of thermo-mechanical properties in the Tyrrhenian-Northern Apennine region, Tectonophysics, 300, 143-158.

Guidotti, C. V. (1989), Metamorphism in Maine: an overview, in Studies in Maine geology; papers to commemorate the 150th anniversary of C. T. Jackson's reports 
on the geology of Maine, edited by R. D. Tucker, R. G. Marvinney, pp. 1-17, Maine Geological Survey, Agusta, ME.

Handy, M. R., A. Mulch, M. Rosenau, and C. L. Rosenberg (2001), The role of fault zones and melts as agents of weakening, hardening and differentiation of the continental crust: a synthesis, in The Nature and Tectonic Significance of Fault Zone Weakening, edited by R. E. Hodslworth, R. A. Strachen, J. F. Magloughlin, and R. J. Knipe, Geol. Soc., pp. 305-332, Special Publications 186, London.

Hatch, N. L., R. H. Moench, and J. B. Lyons (1983), Silurian-Lower Devonian stratigraphy of eastern and south-central New Hampshire: Extensions from Western Maine, Am. J. Sci., 283, 739-761.

Hirth, G., C. Teyssier, and W. Dunlap (2001), An evaluation of quartzite flow laws based on comparisons between experimentally and naturally deformed rocks, Int. J. Earth Sci., 90, 77-87.

Hodges, K. V., C. Wobus, K. Ruhl, T. Schildgen, and K. Whipple (2004), Quaternary deformation, river steepening, and heavy precipitation at the front of the Higher Himalayan ranges, Earth Planet. Sci. Lett., 220, 379-389.

Hollister, L. S., and M. L. Crawford (1986), Meltenhanced deformation: A major tectonic process, Geology, 14, 558-561.

Holyoke, C. W., III, and J. Tullis (2006), Mechanisms of weak phase interconnection and the effects of phase strength contrast on fabric development, J. Struct. Geol., 28, 621-640.

Hubbert, M. K., and W. W. Rubey (1959), Role of fluid pressure in mechanics of overthrust faulting 1: Mechanics of fluid-filled porous solids and its application to overthrust faulting, GSA Bulletin, 70, 115-166.

Husson, L., and T. Sempere (2003), Thickening the Altiplano crust by gravity-driven crustal channel flow, Geophys. Res. Lett., 30(5), 1243 , doi:10.1029/2002GL016877, 4 pp.

Jamieson, R. A., C. Beaumont, M. H. Nguyen, and B. Lee (2002), Interaction of metamorphism, deformation and exhumation in large convergent orogens, J. Metamorph. Geol., 20, 9-24.

Jamieson, R. A., C. Beaumont, S. Medvedev, and M. H. Nguyen (2004), Crustal channel flow 2: Numerical models with implications for metamorphism in the Himalayan-Tibetan orogen, J. Geophys. Res., 109, B06407, doi:10.1029/2003JB002811.

Johnson, S. E., and R. H. Vernon (1995), Stepping stones and pitfalls in the determination of an anticlockwise P-T-t-deformation path: The low-P, high-T Cooma Complex, Australia, J. Metamorph. Geol., 13, $165-183$.

Johnson, S. E., R. H. Vernon, and P. Upton (2004), Foliation development and progressive strain rate partitioning in the crystallizing carapace of a tonalite pluton: Microstructural evidence and numerical modeling, J. Struct. Geol., 26, 1845-1865.

Jolivet, L., H. Raimbourg, L. Labrousse, D. Avigad, Y. Leroy, H. Austrheim, and T. B. Andersen (2005), Softening triggered by eclotization, the first step toward exhumation during continental subduction, Earth Planet. Sci. Lett., 237, $532-547$.

Jones, K. A., and M. Brown (1990), High-temperature "clockwise" P-T paths and melting in the development of regional migmatites: An example from southern Brittany, France, J. Metamorph. Petrol., $8,551-578$.

Kenis, I., J. L. Urai, W. van der Zee, C. Hilgers, and M. Sintubin (2005), Rheology of fine-grained siliciclastic rocks in the middle crust: Evidence from structural and numerical analysis, Earth Planet. Sci. Lett., 233, 351-360.

Koons, P. O. (1987), Some thermal and mechanical consequences of rapid uplift: An example from the Southern Alps, New Zealand, Earth Planet. Sci. Lett., 86, 307-319.

Koons, P. O. (1989), The topographic evolution of collisional mountain belts: A numerical look at the Southern Alps, New Zealand, Am. J. Sci., 289, $1041-1069$
Koons, P. O. (1990), Two-sided orogen: Collision and erosion from the sandbox to the Southern Alps, New Zealand, Geology, 18, 679-682.

Koons, P. O., D. C. Rubie, and G. Frueh-Green (1987), The effects of disequilibrium and deformation on the mineralogical evolution of quartz diorite during metamorphism in the eclogite facies, J. Petrol., 28 $679-700$.

Koons, P. O., P. K. Zeitler, C. P. Chamberlain, D. Craw, and A. S. Melzer (2002), Mechanical links between erosion and metamorphism in Nanga Parbat, Pakistan Himalaya, Am. J. Sci., 302, 749-773.

Koons, P. O., P. Upton, and M. P. Terry (2003a), Threedimensional mechanics of UHPM terrains and resultant P-T-t paths, EMU Notes in Mineralogy, 5, $415-441$.

Koons, P. O., R. J. Norris, D. Craw, and A. F. Cooper (2003b), Influence of exhumation on the structura evolution of transpressional plate boundaries: An example from the Southern Alps, New Zealand, Geology, 31, 3-6.

Lux, D. R., J. J. De Yoreo, C. V. Guidotti, and E. R. Decker (1986), Role of plutonism in low-pressure metamorphic belt formation, Nature, 323, 794-797.

Madec, R., B. Devincre, L. Kubin, T. Hoc, and D. Rodney (2003), The role of collinear interaction in dislocation-induced hardening, Science, 301 , $1879-1882$.

Mecklenburgh, J., and E. H. Rutter (2003), On the rheology of partially molten synthetic granite, J. Struct. Geol., 25, 1575-1585.

Medvedev, S. (2002), Mechanics of viscous wedges: Modeling by analytical and numerical approaches, J. Geophys. Res., 107(B6), 2123, doi:10.1029/ 2001JB000145

Molnar, P., and P. Tapponnier (1981), A possible dependence of tectonic strength on the age of the crust in Asia, Earth Planet. Sci. Lett., 52, 107-114.

Neil, E. A., and G. A. Houseman (1997), Geodynamics of the Tarim Basin and the Tian Shan in central Asia, Tectonics, 16, 58-571

Nelson, K. D., et al. (1996), Partially molten middle crust beneath southern Tibet: Synthesis of Project INDEPTH Results, Science, 274, 1684-1688.

Ori, G. G., and P. F. Friend (1984), Sedimentary basins formed and carried piggyback on active thrust sheets, Geology, 12, 475-478.

Paquet, J., P. Francois, and A. Nedelec (1981), Effect of partial melting on rock deformation: Experimenta and natural evidences on rocks of granitic compositions, Tectonophysics, 78, 545-565.

Paquet, J., P. Francois, and A. Nedlec (2005), Experimental deformation of partially melted granite re visited: Implications for the continental crust, J. Metamorph. Geol., 23, 19-28.

Passchier, C. W., and R. A. J. Trouw (1996), Microtectonics, Springer, Berlin.

Pysklywec, R. N. (2006), Surface erosion control on the evolution of the deep lithosphere, Geology, 34, $225-228$.

Rubie, D. C. (1983), Reaction-enhanced ductility: The role of solid-solid univariant reactions in deformation of the crust and mantle, Tectonophysics, 96, $331-352$.

Rushmer, T. (2001), Volume change during partial melting reactions: Implications for melt extraction, melt geochemistry and crustal rheology, Tectonophysics, 342, 389-405.

Rutter, E. H. (1999), On the relationship between the formation of shear zones and the form of the flow law for rocks undergoing dynamic recrystallization, Tectonophysics, 303, 147-158.

Searle, M. P., and L. Godin (2003), The South Tibetan Detachment and the Manaslu Leucogranite: A structural reinterpretation and restoration of the Annapurna-Manaslu Himalaya, Nepal, J. Geol., 111 , $505-523$.

Searle, M. P., R. L. Simpson, R. D. Law, R. R. Parrish, and D. J. Waters (2003), The structural geometry, metamorphic and magmatic evolution of the Everest Massif, High Himalaya of Nepal-South Tibet, J. Geol. Soc. London, 160, 345-366.
Selverstone, J. (2005), Preferential embrittlement of graphitic schists during extensional unroofing in the Alpa: The effect of fluid composition on rheology in low- permeability rocks, J. Metamorph. Geol., 23, 461-470.

Sibson, R. H. (2004), Controls on maximum fluid overpressure defining conditions for mesozonal mineralization, J. Struct. Geol., 26, 1127-1136.

Stunitz, H., and J. Tullis (2001), Weakening and strain localization produced by syn-deformational reaction of plagioclase, Int. J. Earth Sci., 90, 136-148.

Takeda, Y., and M. Obata (2003), Some comments on the rheologically critical melt percentage, J. Struct. Geol., 25, 813-818.

Thompson, A. B. (2001), Clockwise P-T paths for crustal melting and $\mathrm{H}_{2} \mathrm{O}$ recycling in granite source regions and migmatite terranes, Lithos, 56, 33-45.

Treagus, S. H. (1999), Are viscosity ratios measureable from cleavage refraction?, J. Struct. Geol., 21, $895-901$

Upton, P., P. O. Koons, and D. Eberhart-Phillips (2003), Extension and partitioning in an oblique subduction zone, New Zealand: Constraints from three-dimensional numerical modeling, Tectonics, 22(6), 1068, doi:10.1029/2002TC001431.

Van Staal, C. R., J. F. Dewey, C. Mac Niocaill, and W. S. McKerrow (1998), The Cambrian-Silurian tectonic evolution of the northern Appalachians and British Caledonides: History of a complex west and southwest Pacific-type segment of Iapetus, in Lyell: The past is the key to the present, edited by D. J. Blundell and A. C. Scott, pp. 199-242, Geological Society, London, Special Publication 143.

Vigneresse, J. L., P. Barbey, and M. Cuney (1996), Rheological transitions during partial melting and crystallization with application to felsic magma segregation and transfer, J. Petrol., 37, 1579-1600.

Vilotte, J. P., M. Daignieres, R. Madariaga, and O. C. Zienkiewicz (1984), The role of a heterogeneous inclusion during continental collision, Phys. Earth Planet. Inter, 36, 236-259.

Wall, E. R. (1988), The occurrence of staurolite and its implication for polymetamorphism in the Mt. Washington area, New Hampshire, MS Thesis, Univ. of Maine, Orono.

Whipple, K. X., and B. J. Meade (2004), Controls on the strength of coupling among climate, erosion and deformation in two-sided, frictional orogenic wedges at steady state, J. Geophys. Res., 109, F01011, doi:10.1029/2003JF000019.

Willet, S. D., D. Fisher, C. Fuller, Y. En-Cho, and L. Chia-Yu (2003), Erosion rates and orogenic wedge kinematics in Taiwan inferred from fissiontrack thermochronology, Geology, 31, 945-948.

Williams, C. A., C. Connors, F. A. Dahlen, E. J. Price and J. Suppe (1994), Effect of brittle-ductile transition on the topography of compressive mountain belts on Earth and Venus, J. Geophys. Res., 99, $19,947-19,974$

Wobus, C. W., K. V. Hodges, and K. X. Whipple (2003), Has focused denudation sustained active thrusting at the Himalayan topographic front?, Geology, 31, 861-864.

Woodward, N. B. (1987), Geological applicability of critical-wedge thrust-belt models, GSA Bulletin, 99, $827-832$.

Zeitler, P. K., C. P. Chamberlain, and H. A. Smith (1993), Synchronous anatexis, metamorphism and rapid denudation at Nanga Parbat (Pakistan Himalaya), Geology, 21, 347-350.

Zhang, S., J. D. FitzGerald, and S. F. Cox (2000), Reaction-enhanced permeability during decarbonation of calcite + quartz $=$ wollastonite + carbon dioxide, Geology, 28, 911-914.

W. G. Groome, Department of Earth Sciences, Simon Fraser University, Burnaby, BC, Canada, V5A 1S8. (wesleyg@sfu.ca)

S. E. Johnson and P. O. Koons, Department of Earth Sciences, University of Maine, Orono, ME, USA. 